\title{
Aoristo)))))
}

International Journal of Phenomenology, Hermeneutics and Metaphysics

\section{Uma índicação sobre como tratar filosoficamente o problema da inteligência artificial}

\author{
An indication of how to treat the problem of artificial \\ intelligence philosophically
}

\author{
Prof. Dr. José Atilio Pires da Silveira \\ Universidade Estadual do Oeste do Paraná'
}

\section{RESUMO}

O presente estudo apresenta uma proposta de aproximação ao problema da inteligência artificial. Nosso entendimento é que as abordagens para o problema da IA são de natureza dicotômica, o que causa um impasse que impede o avanço da discussão. A maneira de lidar com a questão da IA forte que sugerimos é o resultado do cruzamento do pensamento de três filósofos do século XX, John Langshaw Austin (1911-1960), Reinhard Koselleck (1923-2006) e Douglas Hofstadter (1945). Austin, nos adverte quanto aos problemas falsos com os quais poderíamos encontrar se a configuração metafísica em que abordamos o assunto fosse dualista do tipo dicotômico. A reflexão sobre os objetivos do projeto de IA é profundamente influenciada por modelos metafísicos dicotômicos, o que torna o aviso de Austin altamente relevante para quem se predispõe a refletir sobre esse problema. Koselleck, apresenta uma possibilidade de superar o impasse dicotômico através de sua visão estratificada do tempo histórico. Na concepção de Koselleck, o tempo histórico é constituído por camadas que não formam pares de oposição, pois todos produzem efeitos um sobre o outro. Seu modelo temporal pressupõe outro arranjo metafísico, no qual as perspectivas de entendimento do que acontece são muito mais variadas e diversas do que as partes constituintes que formam um par dicotômico. Ao pensar o tempo como algo que pode ser estratificado, ele desenvolve uma nova concepção de tempo que não é linear nem circular. Quanto a Hofstadter, ao lidar com a noção de volta estranha, ele apresenta um movimento de pensamento que tem expressão nas artes e na matemática. Um arranjo de pensamento que, em nossa opinião, reúne as condições para superar os limites impostos pelo modo de pensar dicotômico aplicado ao problema da IA.

\section{PALAVRAS-CHAVE}

${ }^{1}$ Email: Jose.Silveira@unioeste.br

Ulma indicação sobre como tratar filosoficamente o problema da inteligêncía artifícial 


\title{
Aoristo)))))
}

International Journal of Phenomenology, Hermeneutics and Metaphysics

Inteligência artificial; IA forte; volta estranha; Austin; Koselleck; Hofstadter

\begin{abstract}
The present study presents a proposal of approach to the problem of the artificial intelligence. Our understanding is that the approaches to the problem of the Al are of a dichotomic nature, what causes a dead-lock which prevents from advancing in the discussion. The way of dealing with the issue of the strong Al we suggest is the result of the crisscrossing of the thinking of three philosophers from the 20th Century, John Langshaw Austin (1911-1960), Reinhard Koselleck (1923-2006), and Douglas Hofstadter (1945). Austin, by adverting us from the false problems with which we might come upon if the metaphysical configuration in which we approach the subject were dualist of dichotomic type. The reflection concerning the goals of the Al project is profoundly influenced by dichotomic metaphysical models, what makes Austin's warning highly relevant to whom predisposes oneself to reflect upon such problem. Koselleck, by presenting a possibility for overcoming the dichotomic dead-lock through his stratified vision of historical time. In Koselleck's conception, historical time is constituted in layers which don't form opposition pairs, for all produce effects on one another. His time model pressuposes another metaphysical arrangement, in which the understanding perspectives of what happens are much more varied and diverse then the constituent parts that form a dichotomic pair. By thinking time as something that can be stratified, he develops a new conception of time which is neither linear nor circular. As to Hofstadter, by dealing with the notion of strange turn, he presents a movement of thought which has expression in arts and mathematics. An arangement of thought wich, in our opinion, gathers the conditions to overcome the limits imposed by the dichotomic way of thinking applied to the Al problem.
\end{abstract}

\section{KEYWORDS}

Artificial intelligence; strong Al; strange turn; Austin; Koselleck; Hofstadter

\section{INTRODUÇÃO}

O presente trabalho possui como principal temática o problema da efetividade do projeto de inteligência artificial. Nele apresentamos uma sugestão sobre como tratar tal problemática e, com isso, indicar um caminho de elaboração de uma resposta à pergunta sobre se o propósito de alcançar inteligência semelhante à humana de modo artificial é, ao menos, admissível.

Um dos objetivos centrais deste trabalho é destacar o papel que a reflexão filosófica ocupa nesse cenário tão marcadamente científico e tecnológico. Se almejamos superar o impasse no qual se encontra o debate em torno do projeto de IA, julgamos ser a transposição de um obstáculo de natureza metafísica, como a dicotomia, uma das tarefas indispensáveis ao esforço de atingir-se tal superação. O problema da inteligência artificial não é só de natureza prática é também de natureza filosófica, não basta que venhamos a nos tornar capazes de construir máquinas tão inteligentes quanto nós, pois se não formos competentes na sua definição e conceituação não

$$
\begin{aligned}
& \text { José Atilio Pires da Silveira } \\
& \text { Toledo, n`5, v. 1(2020) p. 124 163 }
\end{aligned}
$$




\section{Aoristo)))))}

International Journal of Phenomenology, Hermeneutics and Metaphysics

seremos capazes de as reconhecermos enquanto tais.

É inegável a relevância e as influências que a ciência e a tecnologia exercem nesse contexto. Contudo, acreditamos que o horizonte desse debate também seja constituído por elementos e concepções que, embora não sejam de natureza científica, nem tecnológica, possuem o mesmo grau de importância que esses no esforço de produzirse uma resposta minimamente satisfatória ao problema colocado. A problematização do projeto de IA reveste-se de importância filosófica porque, também, nos induz a refletir sobre o que seja o próprio homem e a especular sobre os limites e capacidades do nosso conhecimento.

A publicação do artigo de Alan Turing, no ano de 1950, intitulada Computação e Inteligência (1996) na qual descreve a arquitetura do que ele chamou de máquina-deestado-discreto, máquina com a capacidade de realizar atividades consideradas, até então, exclusivas do pensar humano, promoveu o surgimento de uma nova área de interesse do conhecimento denominada inteligência artificial.

Para aferir a semelhança de capacidade de pensar da máquina-de-estado-discreto com a humana, Turing propôs como teste o jogo da imitação, em que um dos jogadores participantes seria uma dessas máquinas. Dois objetivos foram atribuídos a essa nova área de investigação, sendo um bem mais audacioso do que o outro. O objetivo mais arrojado seria o de construção artificial de um novo homem, dado que almejaria reproduzir artificialmente uma característica natural que distingue o homem de todas as demais coisas. $\mathrm{O}$ mais modesto visaria à construção de um dispositivo capaz de substituir o homem no desenvolvimento de atividades executadas exclusivamente por este, antes do advento da nova tecnologia da máquina-de-estado-discreto. Esses dois objetivos distinguem o projeto de IA forte do projeto de IA fraca. Quando nos referimos, aqui, ao projeto de IA, nos reportamos à sua concepção forte, pois entendemos que a concepção fraca de IA, embora sendo considerada fraca do ponto de vista de seu propósito último, mostra-se mais forte quanto aos resultados práticos já alcançados, derivado da sua atitude de uso da máquina-de-estado-discreto concebida como uma bancada de testes no esforço de compreensão sobre como se dá a atividade de pensamento humana.

A declaração da IA forte de pretender alcançar um objetivo tão ambicioso quanto o da construção artificial de algo que compartilharia com o homem a capacidade que distingue este de todas as demais coisas é provocativa e perturbadora. Esses efeitos resultam do fato da ideia de construir-se um novo homem ir de encontro a um conjunto de crenças e convicções de naturezas filosófica, religiosa e científica idealizadas ao longo da história do pensamento e por provocarem indagações advindas de diferentes áreas de interesse da racionalidade humana, as quais perguntam sobre os limites do conhecimento, a possibilidade de nos definirmos satisfatoriamente, a dependência da tecnologia no processo de evolução humana e a negação da ideia de que a inteligência humana seja o resultado de um ato de criação divina.

A maneira de tratamento que sugerimos para o problema da IA forte é a resultante da interposição dos pensamentos de três filósofos do século XX, John 


\section{Aoristo)))))}

International Journal of Phenomenology, Hermeneutics and Metaphysics

Langshaw Austin (1911-1960), Reinhard Koselleck (1923-2006) e Douglas Hofstadter (1945).

Austin por nos advertir dos falsos problemas com os quais poderemos nos defrontar, se a configuração metafísica com a qual os abordarmos for dualista do tipo dicotômica. A reflexão em torno dos objetivos do projeto de IA é profundamente influenciada por modelos metafísicos dicotômicos, o que torna a advertência de Austin altamente relevante para quem se propõe a produzir uma reflexão em torno de tal problemática.

Koselleck por apresentar uma possibilidade de superação do impasse dicotômico com sua visão estratificada de tempo histórico. Na concepção koselleckeana, o tempo histórico constitui-se em camadas que não formam pares de oposição, pois todas produzem efeitos umas sobre as outras. Seu modelo de tempo pressupõe outro arranjo metafísico, em que as perspectivas de compreensão do que acontece são muito mais vastas e diversificadas do que as constituintes que formam um par dicotômico. Ao conceber o tempo como uma algo que pode ser estratificado ele concebe uma nova concepção de tempo que não é nem linear, nem circular.

Hofstadter, que ao tratar da noção de volta estranha, expõe-nos um movimento de pensamento que adquire expressão nas artes e na matemática. Um arranjo de pensamento que, em nossa opinião, reúne condições de superar os limites impostos pelo modo de pensar dicotômico.

Entendemos que a discussão envolvendo o projeto de IA é permeada por teses filosófico-metafísicas acerca das concepções e definições de homem, inteligência, mundo, conhecimento e tecnologia que influenciam fortemente a compreensão geral do debate inerente a esse conjunto de questões.

A discussão em torno do projeto de IA é bastante influenciada por uma infinidade de ideias que de modo algum são compatíveis com os propósitos deste projeto. Muitas críticas quanto ao sucesso desse empreendimento geralmente se apoiam em concepções filosóficas tão antigas, oriundas de um tempo em que ainda não era cogitada a capacidade do homem construir, com o seu conhecimento, algo que fosse, de certa forma, uma cópia de si. Entretanto, embora distantes no tempo, elas não deixam de produzir efeitos quando defrontadas com algumas das realizações da ciência e da tecnologia atuais, influenciando o ambiente do debate em torno da tentativa de construção de um dispositivo dotado de inteligência como a humana. Tais efeitos não são irrelevantes. Pressupomos ser exatamente eles um dos principais responsáveis pelo impasse na discussão sobre a capacidade de o homem poder, um dia, produzir algo tão inteligente quanto ele próprio.

Em nossa opinião, as críticas dirigidas ao projeto de IA, às quais sustentam que o objetivo desse projeto não tem como ser atingido, só chegam a esta conclusão, porque pressupõem uma concepção dicotômica da metafísica no tratamento das questões relacionadas a ele.

Destacaremos, nos pensamentos de Austin, Koselleck e Hofstadter, os elementos

José Atilio Pires da Silveira

Toledo, n`5, v. 1(2020) p. 124-163 


\section{Aoristo)))))}

International Journal of Phenomenology, Hermeneutics and Metaphysics

de suas análises que servem de sustentação à sugestão que aqui fazemos. Do cruzamento dos pensamentos desses filósofos poderemos verificar que metafísicas de caráter dicotômico se fazem presentes no debate atual sobre IA e, produzem como resultado um impasse, uma situação sem saída, que se apresenta como um limite praticamente impossível de ser superado. Também podemos verificar que as concepções dicotômicas do mundo não conseguem apreender e explicar a complexidade que este possui como um modelo estratificado e um modelo de voltas estranhas são capazes.

\section{A DICOTOMIA COMO ENTRAVE AO DEBATE FILOSÓFICO}

John Langshaw Austin foi um pensador do séc. XX que viu nos usos da linguagem fatores que desencadearam entraves no avanço da reflexão filosófica. Ao comparar a linguagem do homem comum com a dos filósofos identificou diferenças entre elas que o levaram a não aceitar a substituição da linguagem ordinária, nas discussões filosóficas, por uma própria da filosofia. Os termos que fazem parte do vocabulário ordinário além de terem sido submetidos a um exaustivo teste de uso, marcam distinções em seus significados que a nova linguagem não leva em consideração.

Ao assinalar tais diferenças, Austin destacou a necessidade de recuperar-se o emprego do vocabulário ordinário, por este ser portador de uma riqueza de distinções sobre a experiência perceptiva jamais alcançada pelos vocabulários que [...] adotam um ponto de vista acadêmico (Austin, 1993, p. 9, negrito nosso). A abordagem austiniana do problema da percepção é uma reflexão em torno dos efeitos gerados pelo esquecimento da linguagem ordinária ao tratarmos de alguns problemas filosóficos. Ao considerarse a linguagem ordinária inepta para o tratamento dos problemas filosóficos nos tornamos indiferentes ao seu vocabulário e riqueza semântica.

Embora seja reconhecido como o criador da teoria dos atos de fala, o que destacaremos no pensamento de Austin são as duras críticas dirigidas à atividade filosófica apresentadas em Sentido e Percepção (1993). Nessa obra, ele examina alguns problemas relacionados às teorias da percepção que procuram responder à pergunta pelo conteúdo desta e, as compara com as possíveis respostas formuladas pelo homem comum para este mesmo conjunto de questões. Este domínio da reflexão filosófica é marcado pelo enfrentamento do realismo com o idealismo, que se confrontam de tal modo que ambos expressam o maior grau de antagonismo de um para o outro, onde um propõe a anulação do outro.

Tais teorias partem de um mesmo princípio, de que aquilo que percebemos se trata sempre de uma e mesma coisa. Para o realismo o que percebemos são coisas materiais, enquanto para o idealismo são dados dos sentidos. Essa discussão é tão antiga que, para Austin, já não é possível acessar-se aos textos originais que lhe deram início, [...] ao contrário, por exemplo, de doutrinas acerca dos "universais" - já eram bastante antigas no tempo de Platão. (AUSTIN, 1993, p. 8). Por essa razão, Austin escolhe pensadores

Ulma indicação sobre como tratar filosoficamente o problema da inteligêncía artificial 


\section{Aoristo)))))}

International Journal of Phenomenology, Hermeneutics and Metaphysics

contemporâneos seus para buscar identificar as premissas básicas que sustentam ambas posições. Para ele, estes lhe:

[...] parecem fornecer as melhores exposições disponíveis das razões aceitas para sustentar doutrinas que remontam pelo menos a Heráclito, mais completas, coerentes e exatas em sua terminologia do que, por exemplo, as que se encontram em Descartes e Berkeley. (AUSTIN, 1993, p. 7)

A impossibilidade de acesso aos textos que deram origem às doutrinas da percepção não representa um impedimento que torna a reflexão sobre o seu conteúdo uma tarefa sem nenhuma possibilidade de alcançar algum resultado positivo. Austin não vê problema com a falta de acesso às fontes originais dessas doutrinas, pelo contrário; as fontes das quais ele lança mão representam um aprimoramento daquelas, garantindo uma vantagem àquele que se propõe a analisá-las.

De acordo com este filósofo, não há um acordo sobre as razões desta diferença entre elas, pois [...] parecem divergir quanto a saber se a distinção principal que estabelecem é entre duas linguagens ou entre duas classes de entidades. (AUSTIN, 1993, p. 8)

Não seria a mera adoção de um vocabulário mais recente a solução para o impasse, como também não seria a eliminação de todo um vocabulário já disponível. Austin não era contrário à adoção de novos termos ao rol que temos a nossa disposição para pensarmos os problemas filosóficos, pelo contrário. O que não é aceitável, para ele, é o abandono de uma linguagem em detrimento de outra por se considerar essa mais moderna do que aquela. Em várias ocasiões ele enfatiza que uma das principais características da linguagem ordinária é a de ser constantemente renovada com a incorporação de novos termos e significados após estes serem submetidos a um exaustivo teste de uso.

Mas, mesmo assim, é aconselhável ter sempre em mente (a) que as distinções incorporadas ao nosso cabedal de palavras comuns - vasto e, em grande parte, relativamente antigo - não são nem poucas, nem sempre muito óbvias e, quase nunca, tão-somente arbitrárias; (b) que, seja como for, antes de introduzir qualquer alteração por nossa conta, precisamos descobrir com que estamos a lidar; e (c) que essa alteração das palavras, que se passa naquilo que vemos como um pequeno recesso do campo semântico, é sempre passível de repercussões imprevistas no território adjacente. A alteração não é, de fato, tão simples como se supõe, não se justifica nem é necessária com a frequência que se lhe atribui, e em geral é vista como necessária exatamente porque aquilo de que dispomos já se acha erroneamente representado. (AUSTIN, 1993, p. 89) 


\section{Aoristo)))))}

International Journal of Phenomenology, Hermeneutics and Metaphysics

Seu método de abordagem dos problemas filosóficos dá relevância aos diversos significados atribuídos e atribuíveis aos termos que constituem o vocabulário com o qual expressamos nossos pensamentos. A adoção de um novo vocabulário com o consequente esquecimento do antigo representa, antes de tudo, uma perda.

No entanto, isso não significa dizer que tudo aquilo que faz parte do nosso acervo de linguagem deve ser mantido em uso. Sua abordagem do antagonismo entre realismo e idealismo visa mostrar que o mesmo não expressa uma relação de oposição genuína. Por essa razão, um dos principais objetivos do seu trabalho é mostrar que alguns usos de termos e significados não passam de ilusões de linguagem. Torna-se necessária, portanto, a remoção do uso dos mesmos, visto que não auxiliam a reflexão filosófica na superação do impasse gerado por esse tipo de engano.

[...] dissolver as inquietações filosóficas (algumas espécies de inquietação filosófica, não a filosofia inteira), e, também, algo acerca dos significados de algumas palavras ("realidade", "parece", "tem aparência de", etc), as quais, além de filosoficamente escorregadias, são interessantes por si mesmas. Além disso, não há nada tão obviamente maçante quanto a constante repetição de asserções que não são verdadeiras, e que, às vezes, são desprovidas da mínima sensatez; se pudermos reduzir um pouco esse estado de coisas, tanto melhor. (AUSTIN, 1993, p. 12)

Austin está convencido de que o espaço do debate filosófico está cheio de hábitos, argumentos e usos de linguagem que permanecem sem uma razão que justifique a manutenção dos mesmos. Em Sentido e Percepção são várias as referências à necessidade de se levar em consideração o maior número possível das diversas situações de uso de uma palavra, como, também, da atenção que deve ser dada aos avanços nas pesquisas relativas aos fenômenos perceptivos alcançados pelas várias áreas do conhecimento.

Austin não acredita que possa haver um avanço na discussão enquanto ela estiver submetida a um arranjo dicotômico. Sua crítica à relação realismo/idealismo enfatiza que o debate, neste caso em torno do conteúdo das nossas percepções, perde qualquer perspectiva de avanço se não for feito um movimento de saída deste círculo, um movimento que ao ampliar as perspectivas de abordagens nos permitam, ao mesmo tempo, ver o quão limitado é o território demarcado pelos muros daquelas duas doutrinas. Sua crítica à dicotomia é apresentada por meio de uma análise da linguagem. Nessa análise ele busca mostrar que quando o jogo de linguagem é jogado de forma dicotômica, produz-se a falsa constatação de que o debate esteja limitado pelas teses que nele se antagonizam. No máximo poderá haver uma miríade de outras sub-doutrinas que estariam dentro do espectro de ideias delimitado pela relação dicotômica em questão. Seja qual for a pergunta dirigida aos realistas ou, aos idealistas, a respeito do conteúdo das representações sensíveis, eles sempre responderão se tratar ou de coisas materiais, para os realistas, ou de dados dos sentidos, para os idealistas. Para ambas doutrinas, todas as questões e considerações se dirigem para uma só resposta.

Uma índicação sobre como tratar filosoficamente o problema da inteligência artíficial 


\section{Aoristo)))))}

\section{International Journal of Phenomenology, Hermeneutics and Metaphysics}

Esta convergência é, na opinião de Austin, um empobrecimento das abordagens que poderíamos empreender ao debate.

Austin constata que o procedimento convergente de organização do pensamento dá-se, no meio filosófico, desde os seus primórdios. As razões para esta forma de proceder parecem dever-se à clareza e simplicidade, que dão ao esquema uma aparência de maior rigor e precisão de abordagem. E, também, a uma preferência pela criação e desenvolvimento de um vocabulário que não esteja influenciado por ideias que representassem uma certa antiguidade nociva que prejudicasse o avanço da discussão.

O que acontece, como procurarei mostrar, é que as palavras correntes são muito mais sutis em seus usos, e marcam muito mais distinções do que as vislumbradas pelos filósofos, e que os fatos da percepção, tal como descobertos, por exemplo, pelos psicólogos, mas também pelo comum dos mortais, são muito mais diversos e complexos do que se tem pensado. (AUSTIN, 1993, p. 10)

Quando o procedimento de convergência é amplamente empregado, é preenchida uma das condições que favorece a aceitação das dicotomias. Não são somente os significados dos termos de linguagem que são submetidos a essa forma de ordenamento do pensamento, mas também as próprias experiências perceptivas. Importante destacar que essa influência não se dá exclusivamente sobre o homem comum, mas, sobretudo, com os próprios estudiosos dos fenômenos da percepção.

Em Lógica a convergência é uma estratégia de montagem de um procedimento de sustentação em que os elementos que exercem a função de sustentação são de conteúdos e origens distintos, dando à construção uma solidez maior, dada a possibilidade de ser sustentada por diferentes razões. Contudo, não é este tipo de convergência que conferimos à crítica de Austin dirigida à dicotomia. A convergência dicotômica é uma raiz invertida, ela reduz a pluralidade das origens das razões como também, elimina a pluralidade de consequências que podem ser advindas de um conjunto de premissas. Em nossa opinião, Austin nos mostra a convergência como um arranjo que envolve o movimento de uma unidade para outra, enquanto na Lógica ela envolve o movimento de uma pluralidade referindo-se a uma mesma unidade. $\mathrm{Na}$ Lógica, mostra-se que de uma pluralidade de razões poderemos chegar a uma mesma consequência. No modo como o criticado por Austin o que se dá é o inverso, não é a pluralidade o ponto de partida, mas a progressiva rejeição da possibilidade de muitas outras razões.

Não existe uma espécie de coisa que nós percebemos, mas muitas espécies diferentes, cujo número pode ser reduzido (se é que pode) pela investigação científica, e não pela filosofia: sob muitos aspectos, mas não sob todos, canetas são muito diferentes de arco-íris, e estes são

$$
\begin{aligned}
& \text { José Atilio Pires da Silveira } \\
& \text { Toledo, n`5, v. 1(2020) p. 124 163 }
\end{aligned}
$$




\section{Aoristo)))))}

\section{International Journal of Phenomenology, Hermeneutics and Metaphysics}

diferentes sob muitos, mas não sob todos os aspectos, das imagens consecutivas que, por sua vez, sob muitos aspectos, mas não todos, são diferentes de imagens na tela do cinema - e assim por diante, sem que se lhes possa determinar um limite. (AUSTIN, 1993, p. 11)

A perspectiva austiniana é de abertura, de um conjunto de premissas poderemos inferir muitas conclusões distintas, é uma concepção de natureza divergente. Ao invés de restringir o conjunto de possibilidades é exatamente o oposto disso que garantirá uma compreensão mais robusta de mundo.

Isso pode ser visto na análise dos significados de dois termos bastante empregados nas discussões travadas entre o realismo e o idealismo. O propósito de Austin ao fazer a análise dos diferentes significados de expressões como parecer e real é o de nos alertar para a perda ou abandono de significações que essas expressões possuem. Vale lembrar que Austin, com sua perspectiva divergente, empreende um esforço para que seja recuperada a característica polissêmica dessas expressões. Não há razão suficiente para que se escolha um dos seus significados como sendo capaz de cobrir todo campo semântico que tal expressão possui. Esta situação de empobrecimento semântico é fundamental para a construção de dicotomias, pois essas se nutrem de uma eliminação de possibilidades de ser para se imporem enquanto tal.

$\mathrm{Na}$ análise dos usos de parecer, Austin critica a obra de Alfred Jules Ayer (19101989) The Foundations of Empirical Knowledge, em que este se posiciona a favor do idealismo, afirmando que Ayer

[...] us [ou] com muita liberdade as expressões "parecer", "ter aparência de" (look), "parecer", "afigurar-se" (appear), "parecer", "dar a impressão de" (seem) - aparentemente como faz a maioria dos outros filósofos, sem atribuir grande importância à questão de saber qual expressão é usada onde; na verdade deixa implícito, devido à rapidez do seu vôo filosófico, que tais expressões podem ser usadas de modo intercambiável, que não há muito a escolher entre elas. (AUSTIN, 1993, p. 48, grifo nosso)

É bastante evidente que a construção de dicotomias depende da adoção de uma determinada maneira de lidar com palavras e ideias, onde as diferentes forças que aí operam se dirigem para um mesmo ponto, tendo por consequência a eliminação de outros pontos possíveis. No caso de Ayer, a não distinção dos diferentes significados do termo "parecer" servirá de ponto de apoio para que se posicione a favor de um dos membros que forma o par dicotômico dados dos sentidos/coisas materiais.

[...] não é assim; na verdade, as expressões em questão têm usos inteiramente diferentes, e o uso de uma ou outra implica uma grande diferença. Nem sempre é verdade - pois há casos, como veremos, em que usar uma ou outra dá praticamente no mesmo, e contextos em que

Ulma indicação sobre como tratar filosoficamente o problema da inteligêncía artifícial 


\section{Aoristo)))))}

International Journal of Phenomenology, Hermeneutics and Metaphysics

as expressões têm um uso mais ou menos intercambiável. Mas, devido à existência de tais casos, seria um erro concluir que não existe nenhuma diferença específica no uso das palavras; essa diferença existe, e há um grande número de contextos e construções que o demonstram. (AUSTIN, 1993, p. 48)

Austin, por outro lado, parte da ideia de que há relação de sinonímia entre termos da linguagem, situações de uso em que o emprego de uma ou outra não gera alteração do significado que está em uso. Ele identifica três níveis de intercambialidade entre expressões. No primeiro não há intercambialidade entre os termos; no segundo há total intercambialidade e, no terceiro, a intercambialidade é parcial. Iremos nos deter nos casos em que não há intercambialidade visando mostrar que, pelo menos nesses, a perspectiva de convergência semântica gera equívocos. Ao dar relevância à abertura semântica, Austin expõe, assim, a fragilidade do procedimento dicotômico cuja característica principal é a simplificação.

Ao analisar as expressões look, appear e seem, Austin leva em consideração aspectos de natureza sintática para apontar os casos em que não é possível o uso intercambiável destas expressões de linguagem. Tais características servem de indícios para apontar diferenças semânticas sutis que, somente por meio de uma análise criteriosa, como a realizada por Austin, podem ser percebidas. A comparação, entre as expressões acima mencionadas, mostra-nos que umas possuem mais riqueza de participação em construções de linguagem do que outras. Austin nos expõe uma assimetria semântica, por exemplo, entre look e appear, o que torna temerária a substituição de uma pela outra. Ele identifica quatro situações de uso para look e sete para appear. As diferentes situações de uso das expressões devem ser levadas em consideração se não quisermos cair no erro de intercambiarmos livremente expressões que não possuem simetria semântica.

Este procedimento, de levar em conta as diferentes situações de uso e significados, salienta a característica de riqueza semântica que as expressões possuem. A forma austiniana de organizar o cenário desta discussão é diametralmente oposto àquele que sustenta a construção de dicotomias. Enquanto, para Austin, uma expressão abre um leque de opções significativas, por mais simples que seja sua carga semântica; para a concepção de uso da linguagem criticada por ele, o que se dá é exatamente o oposto, em havendo um grande número de possibilidades significativas, elimina-se ou desconsidera-se suas diferenças, fazendo-as, com isso, convergir para uma só. Portanto,

[...] mesmo sem entrar em grandes detalhes, fica bastante claro que as ideias básicas por trás dos usos de look, appear e seem não são as mesmas; e, com muita frequência, onde se usa uma palavra não cabe usar a outra". (AUSTIN, 1993, p. 54) 


\section{Aoristo)))))}

\section{International Journal of Phenomenology, Hermeneutics and Metaphysics}

Mesmo em se tratando de um conjunto tão restrito de expressões o que se afere é que há uma riqueza de significados tal que se torna um desafio empreender qualquer tipo de substituição de uma pela outra.

$\mathrm{Na}$ argumentação de defesa da tese do idealismo formulada por Ayer, é apresentado o argumento da ilusão, em que são empregados termos como look e appear. Tal argumento tinha por propósito inferir que os conteúdos das nossas percepções são dados dos sentidos e,

Baseia-se no fato de que as coisas materiais podem apresentar aparências diferentes a diferentes observadores, ou ao mesmo observador em diferentes condições, e que a natureza destas aparências é, até certo ponto, casualmente determinada pelo estado das condições e do observador. (AUSTIN, 1993, p. 31, negrito nosso)

A princípio, a intenção de Ayer é mostrar que algumas percepções não são seguras o suficiente para que tenhamos certeza de que elas estão nos fornecendo informações sobre as qualidades genuínas de uma determinada coisa. Colocando-se ao lado do pensamento cartesiano, que põe sob suspeição os indícios gerados pela experiência sensível, Ayer estende sua constatação, isto é, não são somente algumas percepções que podem ser classificadas como ilusórias, mas todas elas. Por essa razão Austin faz a seguinte advertência:

\footnotetext{
Desejo agora chamar a atenção, antes de mais nada, para o nome desse argumento - "argumento da ilusão" - e para o fato de ser apresentado como se estabelecesse a conclusão de que pelo menos algumas de nossas "percepções" são enganosas, pois há nessa conclusão duas claras implicações - (a) a de que todos os casos citados no argumento são casos de ilusões, e (b) a de que ilusão e delusão são a mesma coisa. É evidente, porém, que essas duas implicações são totalmente errôneas, e é de grande importância chamar a atenção para isso, pois como veremos, o argumento tira partido de uma confusão exatamente nesse ponto. (AUSTIN, 1993, p. 34)
}

Ao criticar o argumento que serve de fundamento para sustentar a tese de que os conteúdos das nossas percepções são dados dos sentidos, Austin emprega a mesma estratégia da crítica dirigia por ele à intercambialidade dos termos look e appear, como vimos acima. Sua crítica enfatiza que as estratégias empregadas pelos defensores, tanto do idealismo quanto do realismo, caracterizam-se por serem procedimentos convergentes. Procedimentos esses que, à medida que são executados, eliminam a diversidade de experiências perceptivas, resultando no surgimento de um novo elemento amalgamado, possibilitado pela junção dos subprodutos, oriundos do processo de eliminação.

Dois fatores concorrem para tal realização, o procedimento de generalização e a

Ulma indicação sobre como tratar filosoficamente o problema da inteligêncía artifícial 


\section{Aoristo)))))}

International Journal of Phenomenology, Hermeneutics and Metaphysics

falta de atenção aos significados de expressões importantes na formulação da demonstração. Na avaliação que faz da argumentação de Ayer, Austin aponta o procedimento de generalização sendo empregado ao Ayer considerar todos os exemplos apresentados por ele como se tratando de casos de ilusão. Isso é consequência da falta de distinção entre ilusão e delusão. A crítica de Austin é apresentada em duas etapas: na primeira é mostrado que Ayer não é cauteloso ao escolher os casos a serem analisados para sustentar que o conteúdo das nossas percepções são dados dos sentidos, pois trata alguns casos como se fossem de ilusão, quando não o são. O ponto de partida de Ayer é um erro de sentido. Na segunda etapa, Austin justifica sua afirmação do erro de Ayer ao apontar a desconsideração que este faz da distinção entre ilusão de delusão.

O argumento da ilusão se apoia em casos em que a experiência perceptiva mostra-se falha, pois não apresenta as qualidades reais dos objetos percebidos nestas condições. Austin salienta a adoção do procedimento de generalização ao mostrar que nem todos os casos apresentados por Ayer, como sendo casos de ilusão, podem ser considerados como tais. Dos três casos selecionados por Ayer, um deles não pode ser considerado um caso de ilusão, mas de delusão.

Austin compara dois exemplos, dados por Ayer como sendo casos de ilusão, o famoso caso do bastão dentro d'água e o caso das miragens. A primeira constatação é de que em ambos Ayer pressupõe que alguma coisa é percebida nos dois tipos de experiências. De acordo com Austin, isto faz parte da estratégia argumentativa para nos colocar em condições de aceitar a tese de que tudo que percebemos são, na verdade, dados dos sentidos e que toda experiência perceptiva é percepção de alguma coisa. Não haveria experiência perceptiva sem algo que pudesse ser percebido.

No caso do bastão dentro d'água a explicação de Ayer explora uma contradição. $\mathrm{O}$ bastão ora se mostra reto, ora se mostra curvo. Sua explicação afirma que isso só é possível porque há um tipo de coisa, que não é material, que serve de base para a percepção que não se constitui como uma qualidade genuína do bastão. Vale lembrar, são considerados como ilusões porque não propiciam acesso às qualidades reais daquilo que esteja sendo percebido.

No caso das miragens, a argumentação de Ayer apresenta-se como a explicação capaz de dar conta de algumas experiências perceptivas que causam embaraço às explicações que pressupõem as coisas materiais como sendo os conteúdos das experiências perceptivas, já que fica difícil afirmar que seja esse tipo de entidade o constituinte do conteúdo de uma miragem. A vantagem dos dados dos sentidos é que esses não necessitam possuir um correlato que se faça presente numa outra estrutura que não a perceptiva.

Uma pessoa que vê uma miragem, diz Ayer, "não percebe qualquer coisa material, pois o oásis que pensa perceber não existe". Mas "a sua experiência não é uma experiência de nada"; assim, diz-se que apreende 


\section{Aoristo)))))}

International Journal of Phenomenology, Hermeneutics and Metaphysics

dados dos sentidos que são semelhantes, por sua natureza, àquilo que estaria apreendendo se estivesse vendo um oásis de verdade, mas que são enganosos no sentido de que a coisa material que parecem apresentar não está realmente lá. (AUSTIN, 1993, p. 33) (grifo nosso)

A argumentação de Ayer estabelece uma correlação entre fenômenos, quando, de fato, não o são. Ver um bastão dentro d'água e ver uma miragem não são, ambos, casos de ilusão, destaca Austin. O procedimento de convergência de possibilidades é empregado por Ayer, que tipifica todos os casos de conteúdo das nossas percepções como sendo de um só tipo. Parece que Ayer escolhe dentre duas premissas a mais forte. Em sua opinião, os dados dos sentidos se constituem como premissas mais fortes porque podemos constatar que, em muitos casos, não há uma coisa material da qual parecíamos ter percebido algo, pois a coisa percebida não existe, o que então foi percebido? De acordo com o pensamento de Ayer, mesmo nos casos em que há percepção de uma coisa material o conteúdo desta percepção tem de ser um dado dos sentidos, já que ele está presente inclusive naquelas percepções em que não há coisa material sendo percebida. Como uma coisa material não está presente em todas as experiências perceptivas, então, este conceito não pode ser considerado o conteúdo básico das nossas percepções.

Contudo, ao Ayer desconsiderar a distinção entre ilusão e delusão, lança por terra todo seu esforço de explicação ao reduzir seu horizonte de significação. Há uma nítida diferença de significado entre esses dois termos que não nos permite desconsiderá-la. A distinção é simples, num caso o sujeito de observação está em pleno funcionamento, não há problemas com sua estrutura perceptiva, nem com o seu intelecto; enquanto no outro, a percepção é produzida pelo mau funcionamento das estruturas perceptivas e cognitivas que constituem o sujeito de observação.

Aqui, as diferenças mais importantes são que a expressão "uma ilusão" (num contexto perceptivo) não sugere que uma coisa totalmente irreal seja produzida por um passe de mágica - pelo contrário, o que ali está é uma disposição de linhas e setas na página, a mulher no palco com a cabeça num saco preto, as rodas giratórias; ao passo que o termo "delusão" realmente sugere algo de totalmente irreal, que ali não está de modo algum. (As convicções da pessoa que tem delírios persecutórios podem ser completamente desprovidas de fundamento.) Por esse motivo é que as delusões são um caso muito mais grave - algo está realmente mal, e, o que é pior, mal quanto à pessoa que os tem. Mas, quando tenho uma ilusão ótica, por mais perfeita que seja, nada há de errado comigo pessoalmente, a ilusão não é uma pequena (ou grande) peculiaridade ou idiossincrasia de minha parte; é completamente pública, todos a podem ver, e, em muitos casos, podem estabelecer-se procedimentos clássicos para produzi-la. Além disso, se não queremos nos deixar levar pela ilusão, devemos estar de sobreaviso; de nada adiante, porém, dizer ao que sofre de delusões que esteja de

Uma índicação sobre como tratar filosoficamente o problema da inteligência artíficial 


\section{Aoristo)))))}

International Journal of Phenomenology, Hermeneutics and Metaphysics

sobreaviso. O que ele precisa é ser curado. (AUSTIN, 1993, p. 35) (grifos nossos)

A crítica de Austin ao argumento da ilusão afirma que este argumento gera uma rede de implicações que, em três etapas, chega à conclusão de que os casos ilusórios geram enganos a partir de algo que é considerado irreal ou imaterial. Isto se dá porque não é feita a distinção entre ilusão e delusão. Por não fazer tal distinção, Ayer infere que, do mesmo modo que nos casos delusivos, também nos casos de ilusão, algo que não pode ser considerado uma coisa material está sendo percebido.

O modo como o "argumento da ilusão" explora a falta de distinção entre ilusões e delusões é, segundo penso, esse. Enquanto se sugere que os casos para os quais nos chamam a atenção são casos de "ilusão", existe a implicação (derivada do uso comum da palavra) de que ali existe, realmente algo que nós percebemos. Mas então, quando esses casos começam tranquilamente a ser chamados de enganosos, insinuase a sugestão muito diversa de algo sendo produzido magicamente, algo irreal ou de qualquer forma, "imaterial" (AUSTIN, 1993, p. 37, grifos nossos)

O uso da palavra real possui grande relevância em toda esta argumentação e é o uso descuidado dela que faz com que Ayer incorra em erros de avaliação que colocam seu esforço por terra. Na análise deste termo, Austin faz muitas considerações, algumas parecendo entrar em choque com as outras. Por exemplo, ao mesmo tempo em que afirma ser real uma palavra normal, ele também a considera [...] de forma alguma, uma palavra normal; mas sim extremamente excepcional. (AUSTIN, 1993, p. 90) Ele considera real uma palavra normal, porque ela já possui um significado de tal forma estabelecido que não permite aos seus usuários mudá-lo de acordo com as suas vontades, "ao sabor dos caprichos individuais" (Austin, 1993, p. 88) e, por ser antiga o suficiente para que não a consideremos uma palavra inovadora, recente, ou atual. Por sua vez, também, considera real uma palavra fora do comum, porque não possui um significado único, especificável e sempre o mesmo. (AUSTIN, 1993, p. 90) Esse duplo caráter do significado de "real" indica o grau de dificuldade que seu uso impõe. Portanto, se não for usado com a precisão que o seu significado exige, a consequência será um desastre semântico. Confundir o uso destes dois significados de real; um claro e preciso, o outro sutil e variável, implicará a falta de sentido da proposição

A pretensão de se introduzir novas distinções de significado neste tipo de palavra requer que se dê atenção às distinções já presentes no vocabulário disponível, sendo necessário um conhecimento aprofundado do tema que nos impele a querer marcar uma nova distinção e das alterações que estas mudanças produzirão nos campos semânticos adjacentes. Austin não julga ser necessária uma alta frequência de alteração nos significados dos termos do vocabulário disponível. A linguagem necessita de uma

$$
\begin{aligned}
& \text { José Atilio Pires da Silveira } \\
& \text { Toledo, n`5, v. 1(2020) p. 124 163 }
\end{aligned}
$$




\section{Aoristo)))))}

International Journal of Phenomenology, Hermeneutics and Metaphysics

certa estabilidade para exercer com eficiência sua função. Ele está convencido que não devemos descartar as riquezas de significados produzidas ao longo da história de uso de um determinado vocabulário. Entretanto, sua concepção de linguagem se caracteriza por entendê-la como abertura significativa, ou seja, é impossível impedir a introdução de novos elementos e distinções num vocabulário, porém, devemos observar que toda e qualquer tentativa de introdução de uma inovação só deverá ser aceita, se e somente se, de fato ela for pertinente e enriquecedora. A verdade é que, na maior parte das vezes, o sentimento de necessidade de marcar uma nova distinção revela-se mais um desconhecimento das distinções já marcadas do que uma necessidade justificável.

O uso de real é considerado complexo por Austin. Sua complexidade se deve ao fato de que real se apresenta combinado com outros termos que não possuem nada em comum uns com os outros. Ele distingue dois contextos em que empregamos o termo em questão, um em que não sabemos com clareza qual significado deve ser levado em consideração se pretendemos apreendê-lo adequadamente e, outro, em que as condições de apreensão são sabidas. Na sua análise são apresentados casos de usos do termo real em que não temos como saber exatamente qual o significado. Embora, num primeiro momento, pareçam fazer sentido, determinados empregos desta expressão se mostram embaraçosos quando submetidos a uma análise mais minuciosa. Ao mostrar e analisar alguns usos de expressões formadas pela combinação de real com a palavra cor, Austin identifica sete diferentes situações de uso em que esta mesma combinação possui significados distintos em cada uma delas.

Podemos observar que a perspectiva austiniana é de enfatizar o caráter divergente dos significados dos termos empregados nas explicações sobre o conteúdo das percepções. Ao se fazer uso de uma expressão, provocamos uma abertura de sentido que se apresenta como múltipla. Estes casos são classificados por ele como aqueles em que não sabemos exatamente como devemos proceder para termos clareza de quais sejam os significados que lhes são atribuídos.

Dos sete destacamos o terceiro tipo em que a expressão cor real não nos permite compreender qual o seu significado adequado. Quando pergunta pelo significado da pergunta: qual a cor real de um peixe multicolorido que numa determinada profundidade parece ser brilhante, mas, quando pescado, podemos perceber, à luz do dia, que sua coloração é branco-acinzentado. A resposta de Austin é cuidadosa, mas não deixa de ser espantosa, porque afirma que dificilmente saberemos responder sobre a cor real de um ser assim. Ou seja, parece que, embora empregado, o uso de real não faz muito sentido num contexto como este, pois não auxilia em nada a compreensão sobre este aspecto, possuir uma cor. Em comparação com outros usos deste termo, a situação é totalmente diferente, devido ao fato de podermos dizer, com razoável clareza, qual o significado que ele possui ao fazer-se um determinado uso do mesmo.

“Estes diamantes são reais?", “É um pato verdadeiro?" Objetos de joalheria que se assemelham mais ou menos fielmente a diamantes

Ulma indicação sobre como tratar filosoficamente o problema da inteligêncía artifícial 
podem não ser diamantes reais por serem de massa vítrea ou de vidro; o pato pode não ser real porque se trata de uma imitação, ou de um pato de brinquedo, ou de uma espécie de ganso muito parecida com pato, ou porque estou tendo uma alucinação. (AUSTIN, 1993, p. 94)

O uso descuidado de "real" produziu como consequência a sinonímia entre "ilusão" e "delusão", entre o ato de engano dos sentidos e um devaneio ou alucinação. Isto porque o objetivo do argumento da ilusão é mostrar que existem casos em que não há uma coisa material sendo observada, mas sim algo de outra natureza. Numa percepção ilusória nada vai mal, nem com o observador, nem com as condições de observação e, nem com o que é observado. A "normalidade" de uma ilusão reside no fato de que quem é submetido a ela pode tomar consciência de que está sendo iludido, sem que isso altere a experiência perceptiva. O que produz uma delusão são alterações ocorridas com o observador, cuja capacidade de tomar consciência do que se passa está totalmente prejudicada.

A análise austiniana do argumento da ilusão nos mostra que algumas palavras são mais exigentes do que outras quando lhes fazemos uso, "real" é uma delas. Ao não levar em consideração a distinção entre "ilusão" e "delusão" e os múltiplos e variáveis significados de "real", Ayer acreditou ser possível posicionar-se com segurança em favor de um dos pares da dicotomia "dados dos sentidos/coisas materiais".

Austin nos adverte que é preciso entender que as dicotomias não são um modo de arranjo de ideias que nos possibilita a apreensão e compreensão adequadas dos fenômenos e, que devemos dar a devida atenção à riqueza semântica que o vocabulário comum nos põe à disposição. Se levarmos em consideração essas advertências, estaremos menos propensos a cometer equívocos que alguns usos de linguagem suscitam.

\section{A ESTRATIFICAÇÃO COMO MODELO DE COMPREENSÃO}

Reinhard Koselleck aplica o modelo de estratos, termo derivado da geologia, para definir em que consiste o trabalho do historiador, cuja principal tarefa é procurar elaborar um enredo extraído de um aparente caos. A teoria geológica na qual Koselleck se inspira foi formulada pelo dinamarquês Nicolas Steno o qual no século XVII afirmou que as camadas de rochas mais antigas são sobrepostas pelas mais recentes, seguindo uma ordem cronológica e que só é alterada pelo movimento da crosta terrestre.

De acordo com o seu propositor, uma concepção estratificada do tempo apresenta vantagens sobre as concepções tradicionais que concebem o tempo como linear ou circular, porque não pressupõe o tempo como algo ao qual se possa atribuir um e somente um único tipo de movimento. Essas duas concepções, que são antagônicas e excludentes, compreendem o tempo como algo no qual só se realiza um

$$
\begin{array}{r}
\text { José Atilio Pires da Silveira } \\
\text { Toledo, n'5, v. } 1 \text { (2020) p. 124-163 }
\end{array}
$$




\section{Aoristo)))))}

International Journal of Phenomenology, Hermeneutics and Metaphysics

tipo de movimento; se para a primeira o tempo não possibilita retorno algum, para a segunda é exatamente o retorno a marca da temporalidade.

Esse modelo [circular], que destaca o retorno do tempo, é frequentemente atribuído aos gregos; em contraposição, judeus e cristãos teriam desenvolvido o modelo linear. Momigliano já demonstrou que essa oposição é ideologicamente enviesada. Ambos os modelos são insuficientes, pois toda a sequência histórica contém elementos lineares e elementos recorrentes. A circularidade também deve ser pensada em termos teleológicos, pois o fim do movimento é o destino previsto desde o início: o decurso circular é uma linha que remete a si mesma. (KOSELLECK, 2014, p. 19)

Assim como para Aristóteles na Física (IV, 219 b1), o “tempo" é considerado a percepção das diferenças que distinguem um antes de um depois, para Koselleck o "tempo" se caracteriza pela mudança, seja pela diferença entre os seus constituintes, seja pela diferença de ordenamento destes mesmos constituintes e por ser uma categoria hermenêutica que se altera conforme a interpretação dada ao relato daquilo que nele se desenvolve. Para o discípulo de Gadamer, a atividade do historiador só se torna possível a partir de um relato do que acontece e de uma reflexão sobre este relato. $\mathrm{O}$ "tempo" não é o próprio movimento, mas só pode ser percebido através deste.

A abordagem estratificada pretende dar conta das lacunas interpretativas originadas pelo procedimento de exclusão empregado pelas concepções tradicionais do tempo. O conceito de estratificação nos permite relacionar elementos temporais que não parecem, à primeira vista, ter nexo algum. Contudo, isso não implica haver uma relação de total dependência, entre si, dos elementos que formam o arranjo estratificado.

Tentarei em seguida compreender os resultados históricos por meio de uma estratificação temporal que pretende solapar a oposição entre o linear e o circular. Os tempos históricos consistem em vários estratos que remetem uns aos outros, mas que não dependem completamente uns dos outros. (KOSELLECK, 2014, p. 19)

A concepção estratificada do tempo histórico deve ser recebida como um elemento de linguagem. Koselleck a apresenta como metáfora, isto é, uma representação de linguagem que nos permite a compreensão de algo daquilo que tomamos como um objeto de interesse. Assim, os esforços do historiador não se confundem com os de outras formas de conhecimento que se debruçam sobre o desenvolvimento dos acontecimentos. A atividade do historiador aproxima-se da atividade do poeta, pois ambos precisam construir imagens como representação dos fatos históricos, recurso sem o qual não há a possibilidade de compreensão de algo que não possui forma e cujo conteúdo é difuso.

Uma indicação sobre como tratar filosoficamente o problema da inteligência artificial 


\section{Aoristo)))))}

\section{International Journal of Phenomenology, Hermeneutics and Metaphysics}

Na condição de historiador, devo adiantar que não tenho capacidade para fazer afirmações de natureza física ou biológica. Situo-me no campo das metáforas: a expressão "estratos do tempo" remete a formações geológicas que remontam a tempos profundamente diferentes, que se transformaram e se diferenciaram umas das outras em velocidades distintas no decurso da chamada história geológica... Sua transposição para a história humana, política ou social, permite separar analiticamente os diversos planos temporais em que as pessoas se movimentam, os acontecimentos se desenrolam e os pressupostos de duração mais longa são investigados. (KOSELLECK, 2014, p. 19)

Ao afirmar que se situa no campo das metáforas, a perspectiva de Koselleck também se aproxima do pensamento de Giambatista Vico que, na Ciência Nova (1725), defende a tese de que a compreensão do direito natural, [...] tal como os juri-consultos romanos o definem: Direito ordenado pela Providência divina, com princípios sobre todas as necessidades ou utilidades humanas, igualmente observado em todas as nações (VICO, 2006, posição 362, Kindle) só pode ser alcançada pelo estabelecimento de uma relação das leis com Deus. Por não estabelecerem esta relação com o divino é que Grocio, Selden e Pufendorf malograram nas suas reflexões sobre o direito natural. Segundo Vico, nenhum conjunto de indivíduos, ao longo da história, decidiu formar uma nação prescindindo de uma religião que venere uma divindade. Para que haja um conhecimento rigoroso do direito dos povos é necessário o conhecimento das verdades metafísicas que demonstram a existência de Deus. Se, por um lado, não é possível haver conhecimento válido das coisas físicas sem o respaldo das verdades abstratas da matemática, por outro, não há possibilidade de conhecimento científico das coisas morais sem o amparo das verdades abstratas da metafísica.

Há, contudo, uma relação problemática de Vico com a matemática; esta é uma ciência, porém não serve como base metodológica para as outras ciências, como propunha Descartes. Para o filósofo napolitano, nem todos os feitos humanos (como a política, a economia ou a poesia) podem ser compreendidos por métodos matemáticos ou pela pura abstração racional, filosófica, da qual vem o conhecimento da verdade, como no caso do raciocínio exato. Entretanto, estes feitos humanos também não podem ser considerados apenas como fatos, como a física fazia com os fenômenos naturais, pois esses fatos são também feitos. Um objeto de estudo dessa "natureza" requer uma ciência diferente, a qual não teria um grau de racionalidade menor, pois também se utilizaria da filosofia, e nem seria menos verdadeira, pois investigaria feitos humanos. Esta ciência diferente seria a Ciência Nova, ou seja, seria uma terceira forma de cognição, cujo objeto são os fatos feitos pelos 


\section{Aoristo)))))}

\section{International Journal of Phenomenology, Hermeneutics and Metaphysics}

homens e que, por conta disso, parte do certo para se atingir a verdade. (LENZI,VICENTINI, 2002, p. 203)

Embora se inspire num modelo de conhecimento oriundo das "coisas físicas", Koselleck não vai além da transposição, não adotando um método físico-matemático para compreender o tempo. A abordagem do tempo histórico exige um esforço de compreensão dos sentidos possíveis das narrativas das ações humanas. Assim como pensava Vico, tal esforço situa-se no plano do discurso e da linguagem.

Para que seja levado a bom termo o esforço de atribuição de sentido aos acontecimentos que se dão no tempo, Koselleck propõe três tipos de estratos temporais, os quais se relacionam às experiências dos indivíduos e das gerações. $\mathrm{O}$ primeiro é a "singularidade" ou a experiência dos [...] acontecimentos como ocorrências surpreendentes e irreversíveis[...] (KOSELLECK, 2014, p. 21), o tempo histórico é concebido como uma experiência de indivíduos e gerações dos acontecimentos dados no tempo, dados de forma especial, pois servem de marcadores das etapas temporais. O segundo são as "estruturas de repetição" que tornam possíveis as singularidades. Tais estruturas garantem as condições de aparecimento dos acontecimentos singulares, pois [...] sem o retorno do mesmo - ou, pelo menos, de algo semelhante, conforme um planejamento - e sem organização seria impossível que eventos singulares se realizassem. (KOSELLECK, 2014, p. 21). O terceiro é a "transcendência" ou permanência de uma determinada experiência do tempo histórico,

[...] não no sentido de um além, mas no sentido de que se estendem por várias gerações. Todas as unidades de experiência precisam de um mínimo de transcendência: sem ela não haveria uma explicação última - por mais provisória que esta possa ser - e nenhuma experiência poderia ser convertida em ciência. (KOSELLECK, 2014, p. 25)

O cenário no qual se movimenta o historiador é descrito por Koselleck como um contexto de descoberta. Nessas condições, o historiador deverá realizar três ações se pretende alcançar um conhecimento rigoroso e necessário. Entretanto, este conjunto de procedimentos não é suficiente por si só para dar o caráter de 'verdade histórica' das experiências no tempo.

O que é buscado, encontrado e apresentado como verdade histórica nunca depende somente das experiências feitas pelo historiador, tampouco somente dos métodos que ele usa. (KOSELLECK, 2014, p. 27, itálicos nossos)

O historiador necessita de um ímpeto que o lance ao encontro do que é buscado. Sem esse impulso inicial não é possível a realização dos estágios subsequentes. Há uma sequência de acontecimentos que deve ser seguida para que o historiador consiga executar sua tarefa. A proposta de estratificação do tempo configura os próprios

Uma indicação sobre como tratar filosoficamente o problema da inteligêncía artificial 


\section{Aoristo)))))}

International Journal of Phenomenology, Hermeneutics and Metaphysics

estágios de realização da atividade do historiador.

A 'verdade histórica' é algo que se situa num contexto de descoberta, em que o objeto a ser descoberto independe de qualquer outra atividade da parte de quem realiza a busca que não a disposição de realizá-la, mesmo não sabendo o que encontrará pela frente. Ele estabelece um paralelo entre o conceito grego de historie e o alemão de experiência (Erfahrung) para mostrar que a atividade do historiador indica a intenção de se produzir um movimento no sentido de se saber alguma coisa de algo. Isto é, ao mesmo tempo em que uma ação é produzida por um agente, um efeito desta ação é produzido neste. Algo é produzido em nós em decorrência de algo produzido por nós mesmos.

Outra observação etimológica, importante para a orientação da narrativa histórica [Historie]: "historia", em grego, significava o que nós, alemães, denominamos "experiência". "Ter uma experiência" significa ir daqui para lá a fim de experimentar e conhecer algo: tratase, de certo modo, de uma viagem de descoberta. Mas a narrativa histórica só surge como ciência a partir do relato dessa viagem e da reflexão sobre esse relato. Ela é, por definição, a expressão mais pura de uma ciência da experiência. (KOSELLECK, 2014, p. 20)

Nesse sentido, a atividade do historiador consistirá na busca pelos "vestígios da experiência do tempo histórico", condição necessária para que o historiador consiga elaborar sua própria reflexão. $\mathrm{O}$ "tempo histórico" deixa vestígios que se fazem presentes no momento atual. Ideias, representações, compreensões, interpretações, toda atividade e esforço humanos cujo propósito último é o de entender o que acontece, continuam a produzir efeitos mesmo sendo tão antigas quanto a ideia de deus(ses) e outras.

Contudo, existem numerosas repetibilidades que se estendem bem além de uma geração, além até daquela sucessão empiricamente evidente das gerações que ainda conseguem se comunicar oralmente. Esses fenômenos de repetição que ultrapassam os limites do cotidiano podem ser chamados de "transcendentes". Situam-se aqui verdades religiosas ou metafísicas que se fundamentam em enunciados básicos que só muito lentamente se modificam ao longo dos séculos e permanecem disponíveis, mesmo que nem todos os compartilhem. (KOSELLECK, 2014, p. 25)

As mudanças ocorridas no tempo histórico são alterações da "transcendência" das experiências históricas possibilitadas pelas "estruturas de repetição". A tarefa do historiador de encontrar sentido na sucessão dos acontecimentos para, daí, entender como se dão as mudanças deve levar em consideração um duplo cujos membros 


\section{Aoristo)))))}

\section{International Journal of Phenomenology, Hermeneutics and Metaphysics}

compartilham entre si a capacidade de influenciar um ao outro, esta é, segundo Koselleck, a forma de proceder adequada ao propósito de entender as mudanças que ocorrem no tempo histórico. Koselleck acredita que a tarefa do historiador está compreendida entre dois fatores [...] de um lado, os pragmata, as res gestae, os acontecimentos e, de outro, as histórias ou a disciplina da história. (KOSELLECK, 2014, p. 30). As mudanças no tempo histórico decorrem das interações entre esses dois fatores que, como foi dito acima, produzem efeitos um no outro. A tarefa do historiador consiste em identificar os estratos do tempo histórico e aplicar a estes o método de análise adequado e capaz de lhe possibilitar uma atribuição de sentido aos acontecimentos que estão sob seu escopo. Isto implica que as mudanças nos acontecimentos repercutem na maneira como nós os compreendemos, assim como nossa compreensão não deixa de ser um acontecimento.

Oferecem-se então duas possibilidades de analisar autonomamente, também partindo de uma perspectiva temporal, as alterações de experiências ou de métodos, de modo a considerá-las como fator primário das mudanças. Normalmente o historiador tenderá a conceder primazia à mutação da experiência, definindo-se como mero analista ou como narrador, aquele que somente registra. Mas não pode haver dúvida de que uma experiência histórica, quando enquadrada metodologicamente, se transforma em um fator autônomo, causando efeitos muito significativos. Sem a interpretação teológica e escatológica do mundo, feita pela igreja cristã, nem a controvérsia das investiduras, como todas as suas consequências políticas, nem as Cruzadas teriam sido possíveis; tampouco as conquistas ultramarinas pela navegação cristã, nem, evidentemente, a história das guerras civis religiosas no início da era moderna. É possível menosprezar a influência direta de Maquiavel na história, mesmo que ela seja onipresente de forma indireta, mas é impossível negar que a visão histórica de Marx, elaborada com método, rigoroso ou não, tenha tido consequências históricas de caráter mundial, inimagináveis sem Marx. Assim, em primeiro lugar, seria possível elaborar uma história imanente dos métodos que se alimente primordialmente de suas inovações, as quais, apesar dos pressupostos que as condicionam, não seriam completamente dedutíveis deles...

A segunda possibilidade consistiria em fazer a alteração no método decorrer das alterações parciais na experiência. É fácil verificar essa hipótese, pois modificações comprováveis no ambiente social ou político coincidem com inovações metodológicas. (KOSELLECK, 2014, p. 31)

Embora pareça haver uma precedência da experiência sobre o método, ela só o é analiticamente, pois a compreensão de uma determinada experiência do tempo histórico somente será possível se houver um método com o qual se realize esta

Ulma indicação sobre como tratar filosoficamente o problema da inteligêncía artifícial 


\section{Aoristo)))))}

International Journal of Phenomenology, Hermeneutics and Metaphysics

compreensão. Assim como a experiência nos impele a buscar uma forma da sua compreensão, também esta forma de compreensão produz novas experiências. Essa dupla produção de efeitos entre os acontecimentos e nossa compreensão sobre eles é a forma que Koselleck encontrou para superar a tentação de entender essa relação como sendo de natureza dicotômica. Os elementos que formam esse dualismo não interagem de forma a um eliminar o outro, pelo contrário, de acordo com esta maneira de pensar, somente poderemos compreender adequadamente o sentido de tempo histórico se formos capazes de perceber as influências das experiências sobre os métodos e destes sobre aquelas. Como o próprio Koselleck constata, há aí uma circularidade em que ambos componentes se retroalimentam. Mudanças nos acontecimentos muitas vezes são produzidas por nossa compreensão de como eles se deram. Do mesmo modo, nossa compreensão é alterada em razão dos próprios acontecimentos. A tarefa do historiador se desenvolverá na medida em que ele for capaz de perceber as sutilezas das mudanças que ora são produzidas pelos fatos históricos, ora pelos métodos empregados para compreendê-los. Embora ele deixe a possibilidade de identificar outras fontes de mudança de sentido do tempo histórico que não os próprios acontecimentos e os métodos empregados pelos historiadores.

Lançando mão de diferenciações antropológicas nos conceitos de experiência e métodos, tentaremos possibilitar a articulação entre ambos e estabelecer correlações baseadas na premissa de que a história (Geschichte) e a narrativa histórica (Historie), a realidade e seu processamento consciente, sempre remetem uma à outra e se constituem reciprocamente, mas não são completamente derivadas uma da outra. (KOSELLECK, 2014, p. 32)

Procuramos lançar mão desse tipo de abordagem ao tratarmos aqui da viabilidade do projeto de IA. Vemos nesta abordagem duas razões que nos permitem o vislumbre de uma saída para o impasse epistemológico que trava o avanço do debate em torno das capacidades humanas e suas realizações. Primeiro, por não tomar como ponto de partida uma concepção dicotômica dos elementos envolvidos na reflexão sobre a capacidade e limites do conhecimento humano; segundo, por não identificar nas mudanças a manifestação de uma e somente uma causa. Ao afirmar que a experiência no tempo e os métodos para compreendê-la provocam alterações um no outro, Koselleck não deixa espaço para que seja aceita a ideia de que cada efeito é produzido por uma e somente uma causa. A estrutura do tempo e seus momentos, bem como a tarefa do historiador, formam um complexo que não permite a adoção de modelos simples para a sua compreensão.

Para evidenciar o alto grau de complexidade da tarefa de buscar um sentido no aparente caos dos acontecimentos, não bastando a simples adoção de uma categoria para o desempenho de tal tarefa, Koselleck aborda a importância do conceito de 


\section{Aoristo)))))}

\section{International Journal of Phenomenology, Hermeneutics and Metaphysics}

"espaço" no desenvolvimento da pesquisa histórica. Segundo ele, há uma preferência geral dos historiadores em dar relevância ao tempo como categoria especial da história. É mais comum o estabelecimento de relação entre o espaço e o tempo do que entre o espaço e a história. Esta predominância da relação entre espaço e tempo devese à preferência que os historiadores dão à formulação de explicações acerca das mudanças nos acontecimentos e à influência do desenvolvimento da indústria e tecnologia ocorridas na Europa do séc. XVIII.

À primeira vista, é plausível a preferência pelo tempo, em detrimento do espaço, nas teorias da história. Primeiro, por uma razão geral: desde sempre, o historiador, ao perguntar como chegamos à situação atual, diferente da anterior, se interessa por novidades, pela mudança, por alterações. Junta-se a isso uma razão particular: a experiência da singularidade, que se impôs na Europa a partir de 1770, com o horizonte do progresso técnico-industrial e de sua veemente pressão pela mudança (KOSELLECK, 2014, p. 76)

Contudo, para Koselleck, é imprescindível que o "espaço" receba a relevância devida na elaboração de teorias históricas, pois ele também sofre alterações ao longo do tempo.

Minha tese inicial é a seguinte: espaço e tempo representam, como categorias, as condições de possibilidade da história. Mas também o "espaço" tem uma história. O espaço é algo que precisamos pressupor meta-historicamente para qualquer história possível e, ao mesmo tempo, é historicizado, pois se modifica social, econômica e politicamente. (KOSELLECK, 2014, p. 77)

A simplificação no uso de categorias não é a estratégia adequada para a formulação de teorias históricas, pois esta forma de procedimento metodológico determina um empobrecimento e consequente perda de rigor e capacidade explicativa. O destaque dado por Koselleck à distinção entre as condições espaciais meta-históricas e os espaços históricos humanos enfatiza a necessidade de ser feita uma abordagem que não empobreça o horizonte de reflexão em torno dos acontecimentos que interferem na ação humana.

Há condições espaciais naturais que, por sua disponibilidade técnica, econômica ou política devem ser levadas em conta como condições de possibilidade da ação. O fato de a África do Sul não ter um litoral europeu à sua frente, como a Argélia, modifica fundamentalmente o status da guerra civil que ameaça o sul da África. A solução política que De Gaulle adotou não poderia ser obtida tão facilmente na África do Sul. Portanto, a situação geográfica é uma das condições do desesperado domínio da minoria branca, diferentemente do que

Ulma indicação sobre como tratar filosoficamente o problema da inteligêncía artifícial 


\section{Aoristo)))))}

\section{International Journal of Phenomenology, Hermeneutics and Metaphysics}

ocorreu com o domínio dos franceses na Argélia. (KOSELLECK, 2014, p. 80)

Uma investigação histórica que pretenda oferecer uma explicação rigorosa dos acontecimentos da história humana não deve levar em consideração somente aspectos humanos propriamente ditos, mas, também, fatores que afetam a própria ação do homem no tempo. Isolar a ação humana dos fatores que lhe propiciam e causam modificações não é uma alternativa metodológica viável, pois a pesquisa histórica não deve se limitar àquilo que pertence exclusivamente ao humano. A pesquisa histórica deve ir além do humano para entender o seu agir na história.

Tucídides explica a longa duração da Guerra de Troia pelo número insuficiente de embarcações capazes de atravessar o Mar Egeu para conquistar a cidade. Como se vê, as condições geográficas metahistóricas dos espaços de ação humanos se modificam, dependendo de como estão sujeitos ao domínio econômico, político ou militar. Ou, formulando-se de modo teórico: a repentina transformação de situações meta-históricas (para usar uma expressão de Ratzel) em espaços históricos faz parte da investigação de uma teoria da história. Sua utilização, implícita ou explícita, se manifesta em toda a historiografia. (KOSELLECK, 2014, p. 81)

Há um processo de historicização de todos os elementos que produzem influência na ação humana. Tal perspectiva impõe um modelo explicativo que não permite a simplificação dos componentes que possibilitam a produção de uma determinada representação dos acontecimentos. A proposta de Koselleck de tomar emprestada da geologia a concepção de estratos nos permite compreender as inconsistências dos esforços humanos de entendimento dos acontecimentos ao longo do tempo. Não estamos diante de um acontecer único que se desenrola inexoravelmente. $\mathrm{O}$ desenvolvimento da história parece seguir o mesmo padrão que a "pressão de seleção" na biologia. Não há um telos a ser buscado, um propósito último a ser alcançado, uma orientação de rumo. Os acontecimentos históricos, assim como as mudanças nos organismos biológicos, não se submetem a objetivos alcançáveis e preestabelecidos. Podemos perceber as mudanças e produzir explicações para um determinado conjunto de fenômenos que se dão no tempo, mas essa condição não nos assegura a compreensão do que realmente se passa. Essa é uma das razões que explica as diferenças de rumo das teorias que visam entender historicamente o sentido dos acontecimentos. Conforme nossa existência se dá no tempo, a necessidade de mudanças nas teorias que tratam do desenvolvimento deste acontecer se apresenta de tal forma que nossos esforços parecem produzir poucos resultados úteis, a não ser a esperança de sermos menos suscetíveis a eles. 


\title{
Aoristo)))))
}

International Journal of Phenomenology, Hermeneutics and Metaphysics

\begin{abstract}
Comparados com os 5 bilhões de anos da nossa crista planetária e comparados com o 1 bilhão de anos de vida orgânica nessa crosta, os cerca de 10 milhões de anos de existência do homem simiano representam um período curto, e os 2 milhões de anos dos quais temos prova da produção de ferramentas são ainda mais curtos. Sem dúvida, as condições geológicas e geográficas, biológicas e zoológicas, ou seja, todas as condições meta-históricas de determinação do espaço humano, exercem uma influência muito mais marcante durante essa época do que em fases posteriores da nossa história. O ser humano sabe se aproveitar do ambiente mesmo sem poder controlá-lo. (KOSELLECK, 2014, p. 84).
\end{abstract}

Essa condição de seres que possuem consciência do tempo e dos acontecimentos que nele se dão não nos possibilita ir além da mera tomada de consciência, pois toda tentativa de ir além sofre alterações provocadas pela interferência de fatores que não têm como ser antecipados. Tais interferências aumentam à medida que avançamos no tempo. Ao mesmo tempo que aumentamos nossa compreensão dos acontecimentos, também há um aumento na necessidade de mudança da compreensão dos mesmos. Entretanto, essa situação não nos desestimula a perseguir o entendimento dos acontecimentos no tempo. Quando trata da hermenêutica de Gadamer, Koselleck afirma que

[...] assim como a teologia, a jurisprudência, a poesia e suas interpretações, também a história (Geschichte) é vista como uma subdivisão da compreensão da existência. O homem, projetado para compreender, não tem outra opção senão conferir sentido à experiência da história, ou, por assim dizer, assimilá-la hermeneuticamente. (KOSELLECK, 2014, p. 92)

Embora nossos esforços não alcancem o resultado desejado, isso não parece ser suficiente para os abandonarmos e vivermos nossas vidas sem perguntar pelo sentido do que acontece. Sem dúvida, parece que estamos condenados a compreender. Contudo, isso não nos permite deduzir que haja um progresso na compreensão dos acontecimentos dados no tempo, já que não há um modelo ideal que sirva de parâmetro de comparação para avaliar-se o grau de proximidade do que acontece com o que é idealizado. Há a necessidade de incrementar-se nossas categorias para que compreendamos de forma mais adequada os acontecimentos. Ao relacionar a hermenêutica às condições de possibilidade de elaboração de uma teoria geral da história Koselleck distingue, remetendo-se a Gadamer, os fatos da linguagem empregada no relato destes. Haverá sempre uma oposição, uma fronteira que marca uma diferença fundamental que torna o objetivo da compreensão do que acontece um objetivo inalcançável, pois [...] a superioridade daquilo que deve ser compreendido nunca pode ser completamente alcançada por qualquer interpretação. A temática da teoria da história é um caso especial, que toda linguagem tenta, em vão, esgotar. (KOSELLECK, 2014, p. 106)

Ulma indicação sobre como tratar filosoficamente o problema da inteligêncía artifícial 


\section{Aoristo)))))}

International Journal of Phenomenology, Hermeneutics and Metaphysics

As teorias da história devem buscar ir além dos textos e relatos dos fatos a que se remetem, a tarefa do historiador, difere das do teólogo, do jurista e do filólogo que se apoiam na linguagem para desempenhar suas tarefas.

O mesmo não ocorre com o historiador: basicamente, ele se serve dos textos apenas como testemunhas, para extrair uma realidade que existe além deles. Portanto, mais do que todos os outros exegetas de textos, ele destaca um fato extratextual, apesar de reconstituí-lo por meios linguísticos. Parece até uma ironia. Na comparação com as ciências do espírito, o historiador depende menos de textos do que o jurista, o teólogo ou o filólogo. Ao serem transformados em fontes pelas perguntas que ele formula, os textos possuem apenas um valor indicativo para as histórias que ele deseja conhecer. (KOSELLECK, 2014, p. 107)

Com isso, Koselleck expõe a necessidade de uma constante ampliação e modificação dos elementos empregados pelo esforço de compreensão dos acontecimentos dados no tempo. Uma vez que esse esforço se mostra como expressão da linguagem, e os fatos não se resumem à narrativa que deles fazemos, a atitude do historiador deve ser a de não colocar a linguagem como ponto de chegada. A narrativa dos fatos históricos é meramente um ponto de partida para a compreensão da história, não a própria história. Nossas origens culturais, como afirma Umberto Eco, atribuem a um ato de fala o começo de toda a história.

A nossa história, em comparação com numerosíssimas outras histórias,
tem a vantagem de poder começar desde o Início. Antes de mais nada,
quem fala é Deus, que, ao criar o céu e a terra, diz: "Faça-se a luz". E
logo a seguir desta palavra divina, "Fez-se a luz" (Gênesis 1, 3-4). A
criação aconteceu por um ato de palavra, e somente nomeando as
coisas que via, cria Deus sucessivamente, conferindo-lhes um estatuto
ontológico: "E Deus chamou a luz 'dia' e as trevas 'noite' [...] (e)
declarou o firmamento 'céu'". (ECO, 2001, p. 25)

A concepção estratificada do tempo histórico proposta por Koselleck apresentase como alternativa teórica que nos permite ver o emaranhado de inconsistências gerado pelo esforço de interpretação que visa dar sentido ao que acontece como uma totalidade. Os elementos envolvidos nesta trama adquirem performances que se alteram conforme o enredo se desenvolve, a ponto de o próprio esforço de compreensão ter diferentes interpretações quanto ao seu significado e propósitos. A concepção de Koselleck nos mostra que é justamente a inconsistência a característica que se sobressai quando diferentes interpretações dos acontecimentos históricos são relacionadas. Tais interpretações se apresentam com diferenças suficientes que nos 


\section{Aoristo)))))}

International Journal of Phenomenology, Hermeneutics and Metaphysics

permitem ver seus contornos e limites.

A abordagem koselleckeana nos possibilita compreender e relacionar os diferentes resultados a que chegaram os historiadores no percurso da história, mas não resolve as inconsistências propriamente ditas. Elas são consideradas como inerentes ao processo. Não há perspectiva para uma proposta que vise a elaboração de uma teoria unificadora geral capaz de solucionar todas as inconsistências geradas pelo esforço de encontrar sentido no que acontece. Tal abordagem evidencia que, mesmo distantes no tempo, os estratos gerados pelas interações dos elementos históricos, não deixam de produzir seus efeitos posteriormente. Os novos estratos na verdade se devem exatamente àqueles que se sobrepõem. $\mathrm{O}$ esforço teórico do historiador apresenta-se como uma rede de inconsistências que se acumulam umas sobras as outras, interligando-se e constituindo um todo que se mantém pela constância das suas forças de oposição e coesão.

Essa arquitetura da inconsistência, em que diferentes contribuições do pensamento se sobrepõem umas às outras, sem que isto represente a substituição da camada mais antiga pela mais nova, é a característica do pensamento de Koselleck que devemos considerar na reflexão em torno do objetivo da IA. A discussão em torno da possibilidade de obtenção de inteligência de modo artificial possui várias camadas de compreensão que se deram ao longo da história do pensamento. Esses estratos de pensamento, independente da época em que surgiram, continuam a produzir efeitos uns sobre os outros, influenciando a reflexão atual. O resultado disso é uma elaboração em que as partes não se articulam de forma a mantê-la erguida. Contudo, não devemos nos deixar seduzir pela busca de uma saída redentora, que remova do nosso horizonte de reflexão todas as inconsistências que levam ao colapso dos nossos esforços e nos apresente, assim, um modelo em que todas as explicações sejam complementares umas às outras, dando um alento à ideia de que é possível a elaboração de uma teoria que seja capaz de unificar todas as perspectivas de tratamento da questão.

\section{A NOÇÃO DE "VOLTA ESTRANHA" COMO SUPERAÇÃO DA DICOTOMIA}

Na obra Gödel, Escher, Bach: um entrelaçamento de gênios brilhantes (2001), Douglas Hofstadter nos apresenta a noção de volta estranha. Essa noção, de acordo com o registro de Hofstadter (2001),

[...] não foi inventada por Escher, mas sim por Roger Penrose, matemático britânico, em 1958. Contudo, o tema da volta estranha já se encontrava presente na obra de Escher em 1948, ano em que desenhou Drawing Hands. (HOFSTADTER, 2001, p. 16) 


\section{Aoristo)))))}

International Journal of Phenomenology, Hermeneutics and Metaphysics

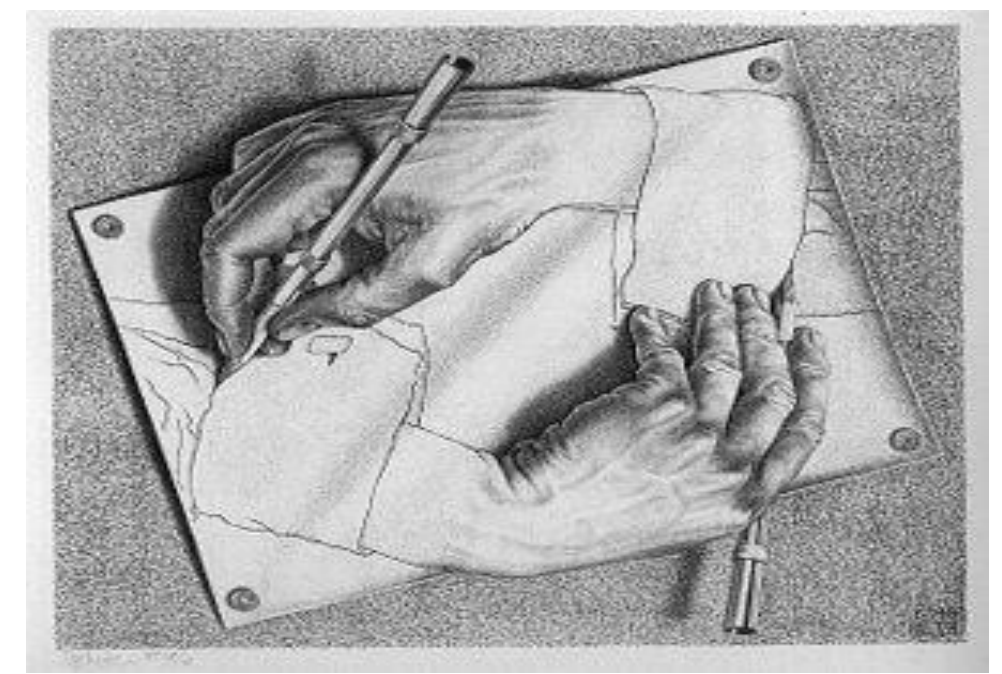

Figura 1: Drawing Hands, M. C. Escher, 1948

Na verdade, como podemos ver na exposição de Hofstadter, o emprego da noção de volta estranha é bem mais antigo que a sua invenção por Roger Penrose (1931). O autor deixa isso claro quando optou por colocar no título de sua obra uma menção explícita e direta às obras artísticas de Escher e Bach, e matemática de Gödel, produzidas antes da publicação do trabalho de Penrose.

Penrose se ocupou com o problema de as máquinas serem capazes de ter consciência e sobre as dificuldades de explicação de como essa se dá em $O$ grande, o pequeno e a mente humana (1998). Nela ele se refere à noção de volta estranha quando aponta os limites da explicação da consciência baseada nos princípios da física atual.

De acordo com o seu pensamento, os procedimentos não computáveis da inteligência humana não podem ser descritos corretamente pela física contemporânea, eles só seriam corretamente descritos por um novo tipo de física que fosse capaz de elaborar novas explicações com maior grau de exatidão ao dispor de um conceitual mais robusto e distinto do atual. Para ele, a mente é uma espécie de ponto de encontro da mecânica clássica com a física quântica.

Na referida obra (1998), Penrose coloca em discussão a relação do mundo físico com o mundo mental. A relação entre as escalas abordadas pela física não gera complementaridade, pelo contrário, as leis que as descrevem são tão distintas ao ponto de serem consideradas incompatíveis, parecem descrever mundos completamente distintos, quando na verdade se tratam apenas de escalas diferentes de um mesmo mundo.

Uma das razões pelas quais optei por dividir minhas descrições das leis físicas entre dois capítulos, a saber, o Grande e o Pequeno, é que as leis que governariam o comportamento em grande escala do mundo e aquelas que o fazem em pequena escala parecem ser muito diferentes (PENROSE, 1998, p. 18) 


\section{Aoristo)))))}

International Journal of Phenomenology, Hermeneutics and Metaphysics

Penrose possui uma representação tripartite de mundo constituída de três instâncias. É da relação entre esses elementos que se origina a forma como o mundo se apresenta a nós. As três instâncias de mundo relacionadas são: o mundo das leis matemáticas ou mundo platônico, o mundo físico e o mundo mental. Como observado na figura 2

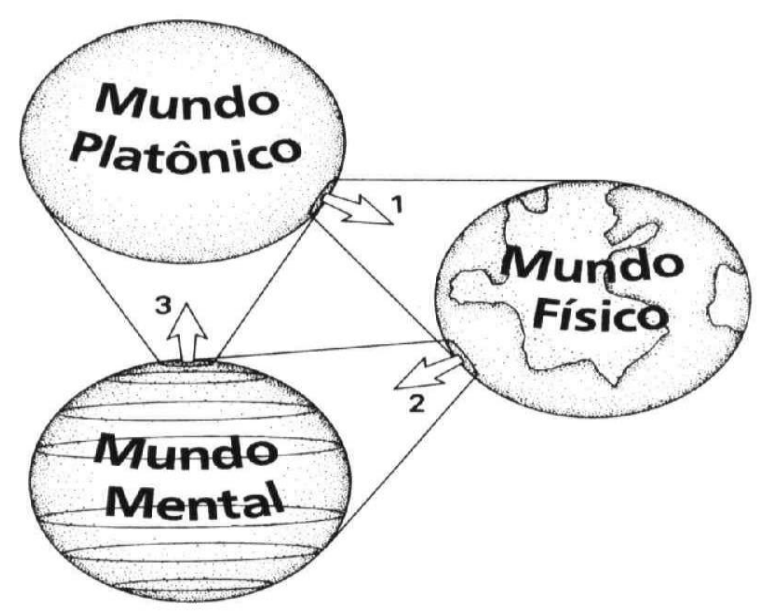

Figura 2: Penrose (1998, p. 109)

Tal posicionamento é considerado inusitado, pois inverte a relação de compreensão entre o mundo e o conhecimento matemático.

Sua posição geral é algo surpreendente, pois ele defende a existência de um mundo matemático platônico que gera, por assim dizer, o mundo físico. Isso se opõe ao que normalmente se crê, quando se mantém que as investigações sobre o universo é que nos induzem a construir determinadas teorias matemáticas (cálculo diferencial e integral, teoria do potencial, análise vetorial, etc.); ou seja, que a matemática nos ajuda a compreender o real, mas que as estruturas matemáticas não são os componentes últimos do universo. (NEWTON DA COSTA, 2008, s.p.)

As interações entre essas instâncias do mundo são o que ele denomina "mistérios".

Acho que existe um problema fundamental com a ideia de que a mentalidade nasça da fisicalidade isso é algo com que os filósofos se preocupam, por muito boas razões. As coisas de que falamos na física são matéria, coisas físicas, objetos massivos, partículas, espaço, tempo, energia etc. Como poderiam os nossos sentimentos, a nossa percepção do vermelho ou da felicidade ter algo a ver com a física? Vejo isso como 


\section{Aoristo)))))}

International Journal of Phenomenology, Hermeneutics and Metaphysics

um mistério. (PENROSE, 1998, p. 107)

Para ele ainda se faz necessária a elaboração de uma explicação sobre como os acontecimentos do mundo físico correspondem de forma exata àquilo que as leis da matemática descrevem, assim como a relação entre o mundo físico e o mundo mental.

Para indicar a necessidade de um novo modelo de explicação, Penrose dá como exemplo a experiência de Libet e Kornhuber que trata da relação entre o nosso comportamento e a atividade cerebral. Essa experiência visava mensurar a diferença entre o início de uma atividade cerebral e a tomada de consciência de uma ação sofrida ou praticada. De acordo com a interpretação dos seus resultados, há um lapso de tempo entre o início da atividade no cérebro e o momento em que as pessoas julgam tomar consciência do objeto dessa atividade.

Precisamos de meio segundo até nos tornarmos conscientes de algum acontecimento. Então, tentamos fazer a consciência funcionar, para fazer alguma coisa com ele. Precisamos de outro segundo para que o livre-arbítrio faça alguma coisa - ou seja, precisamos, no total, de um segundo e meio. Assim, se algo exigir uma resposta conscientemente deliberada, precisamos de cerca de um segundo e meio antes de podermos fazer realmente uso dela. (PENROSE, 1998, p. 147)

No seu entendimento, isso não faz sentido, pois necessitaríamos de um tempo demasiado longo para deflagrarmos uma ação consciente. Ele não confia que levemos tanto tempo para que uma resposta seja dada.

Ele desconfia da medição de Libet e Kornhuber ao cogitar a hipótese de que a interpretação da experiência realizada por eles possui um erro. Este erro estaria na escala de interpretação das atividades envolvidas na tomada de consciência que empregaria um modelo físico inadequado para esse fim, neste caso, o da física clássica. Como para ele a física clássica não é capaz de descrever os fenômenos que se encontram no nível das subpartículas, se faz necessária uma nova física, que se anuncia através da mecânica quântica. Libet e Kornhuber empregam um modelo de compreensão que não se ajusta de modo adequado ao fenômeno que pretende descrever. Ele não chega a afirmar categoricamente que a mecânica quântica seja a expressão exata de uma nova física, mas ela é, ao menos, um pensamento que impulsiona o surgimento desse novo campo de conhecimento.

Minha maneira de encarar isso é que pode muito bem haver algo na maneira como interpretamos essas experiências que faça alguma suposição de que a física que estamos usando seja basicamente a física clássica. Lembremo-nos do problema do teste de bombas, quando falamos acerca de contrafactuais e do fato de que eventos contrafactuais poderiam ter uma influência sobre as coisas, ainda que

$$
\begin{aligned}
& \text { José Atilio Pires da Silveira } \\
& \text { Toledo, n`5, v. 1(2020) p. 124 163 }
\end{aligned}
$$




\section{Aoristo)))))}

International Journal of Phenomenology, Hermeneutics and Metaphysics

não ocorram realmente. $\mathrm{O}$ tipo comum de lógica que se usa tende a levar ao erro se não se toma cuidado. Temos de ter em mente como se comportam os sistemas quânticos, e assim pode ser que algo estranho esteja acontecendo nessas contagens de tempo, por causa da nãolocalidade quântica e dos contrafactuais quânticos. E muito difícil entender a não-localidade quântica dentro do quadro da relatividade restrita. Minha interpretação é que, para entender a não-localidade quântica, vamos precisar de uma teoria radicalmente nova. Essa nova teoria não será apenas uma ligeira modificação da mecânica quântica, mas sim algo tão diferente da mecânica quântica-padrão quanto a relatividade geral é diferente da gravidade newtoniana. Teria de ser algo com um quadro conceitual completamente diferente. Nessa interpretação, a não-localidade quântica estaria incorporada à teoria. (PENROSE, 1998, p. 147)

A noção de não-localidade quântica é fundamental quando se tem por propósito a realização de uma medição mais precisa desses fenômenos. Essa noção é que nos permitirá encontrar sentido para aquilo que, de acordo com o conhecimento atual, faz sentido algum.

A compreensão da consciência, do pensamento e de outras atividades de nível superior depende da compreensão de fenômenos, supostos responsáveis pelo surgimento dessas capacidades, que ocorrem numa escala muito breve do tempo, "essa escala de tempo é de cerca de $10^{-43}$ de segundo e com frequência é chamada escala de tempo de Planck, ou "crônon" (PENROSE, 1998, p. 21).

Os fenômenos que nos permitiriam compreender a consciência e o agir inteligente estariam próximos dos limites dessa escala. Para se ter uma ideia, "esta escala de tempo é muito mais breve do que qualquer coisa experimentada na física de partículas. Por exemplo, as partículas de vida mais curta, as chamadas ressonâncias, duram cerca de 10-23 de segundo" (PENROSE, 1998, p. 21).

Aqui ele emprega a noção de volta estranha para mostrar a necessidade de elaboração de um novo aparato conceitual que nos dê a possibilidade de compreender os fenômenos que fogem, atualmente, da nossa compreensão. A volta estranha é apresentada na forma de uma imagem que ele denominou de "triângulo de impossibilidades", o qual não parece estar corretamente desenhado ao ser visto na sua totalidade. Porém, quando ele é decomposto para ser analisado em que parte se encontra o erro, nenhuma delas apresenta ter algum problema. É necessário que vejamos a figura de uma nova maneira se quisermos sair do paradoxo criado pela comparação da visão geral com a visão parcial do objeto.

Penrose não está convencido de que chegaremos a compreender a relação entre o nosso pensamento e o mundo, mas, também, não nos diz que devamos encarar com resignação nossa ignorância acerca dessa relação. No entanto, não deixa de considerar que [...] é importante reconhecer quando ocorrem quebra-cabeças e mistérios. Mas o mero fato de estar acontecendo algo muito intrigante não significa que algum dia seremos

Ulma indicação sobre como tratar filosoficamente o problema da inteligência artificial 


\section{Aoristo)))))}

International Journal of Phenomenology, Hermeneutics and Metaphysics

capazes de entende-lo. Com esse misto de arrojo e ceticismo é que ele afirma a necessidade de conhecermos melhor acontecimentos que se apresentam a nós de forma inusitada, pois, talvez esteja na compreensão destes a explicação do surgimento da consciência, da inteligência e do pensamento.

Newton da Costa (1929) afirma que Hofstadter tratou o tema das voltas estranhas de maneira semelhante à de Penrose, pois ele recorreu a analogias (nem sempre óbvias) entre as realizações de Gödel, Escher e Bach para tentar esclarecer aspectos da atividade cognitiva, em particular do significado da inteligência artificial.

Hofstadter relaciona as intuições de paradoxo (Gödel), de escada (Escher) e de escala musical (Bach) para descrever a noção de volta estranha (strange loop). Nos deteremos na descrição que ele faz dessa noção presente na obra de Mauritis Cornelis Escher. Fizemos tal opção por entendermos que é correto o entendimento de Richard Rorty (1994) de que as imagens proporcionam uma compreensão mais imediata e acessível dos problemas, pois "são as imagens mais do que as proposições, as metáforas mais que as afirmações que determinam a maior parte das nossas convicções filosóficas" (RORTY, 1994, p. 27)

Hofstadter apresenta uma explicação de como foram possíveis as criações desses gênios que superaram os limites impostos pela maneira de pensar de suas épocas. No entanto, seu interesse principal não é explicar o contexto de criação dos gênios de Gödel, Escher e Bach, sua pretensão é a de abordar o problema da auto-referência, movimento de pensamento que possibilita um ver-se a si mesmo, um problema que ocupa a filosofia desde o seu início. Hofstadter pressupõe que a consciência é uma emergência do sistema mente/cérebro. Quando se referir a um sistema hierarquizado de regras, ele não deixará de emprega-la fazendo referência ao funcionamento do cérebro humano.

A noção de volta estranha é definida como um movimento que revela algo de inusitado e extraordinário.

O fenômeno das voltas estranhas ocorre sempre que, quando nos movemos para cima (ou para baixo) através dos níveis de um sistema hierárquico, encontramo-nos, inesperadamente, de volta ao lugar de onde partimos. (HOFSTADTER, 2000, p. 11)

Existem diferentes tipos de voltas estranhas, umas sendo mais apertadas do que outras, isso é determinado pelo número de etapas ou dos níveis que um determinado sistema hierárquico possui, podendo a mesma completar o seu percurso cíclico em um só passo ou etapa. A realização desse movimento só é possível se houver uma ruptura com a forma dicotômica de arranjo de ideias. Isso pode ser constatado quando da análise de algumas obras do artista holandês em que diferentes perspectivas da realidade e da imaginação são interpostas para compor uma imagem que é transformada, em várias etapas, até retornar, num salto inusitado, a sua forma inicial. 


\section{Aoristo)))))}

International Journal of Phenomenology, Hermeneutics and Metaphysics

Escher realizou voltas estranhas de muitas maneiras diferentes e elas podem ser arranjadas segundo a rigidez da volta. A litografia Ascending and descending (Subindo e descendo) (figura 6), em que os monges caminham eternamente em volta, e a versão mais aberta, uma vez que tantos são os passos envolvidos antes que o ponto de partida seja de novo alcançado. Waterfall apresenta uma volta mais apertada, que, como já observamos, envolve apenas seis passos definidos. Podese pensar que haja aqui certa ambiguidade na noção de "passo" - não se poderia dizer, por exemplo, e com igual razão, que Ascending and descending contem quatro níveis (escadas) ou quarenta e cinco níveis (degraus)? E bem certo que existe uma indefinição inerente na contagem dos níveis, não só nos desenhos de Escher, mas também em sistemas hierárquicos de níveis múltiplos. Posteriormente, aprimoraremos nosso entendimento a respeito dessa indefinição. Mas não nos distraiamos demais por agora! A medida que apertamos nossas voltas, chegamos ao notável Drawing hands (Mãos que desenham) (figura 135), no qual cada uma das mãos desenha a outra: uma volta estranha de dois passos. E, finalmente, a mais apertada de todas as voltas estranhas e realizada em Print gallery (Galeria de gravuras) (figura 142): um quadro de um quadro que contém a si próprio. (HOFSTADTER, 2000, p. 12)

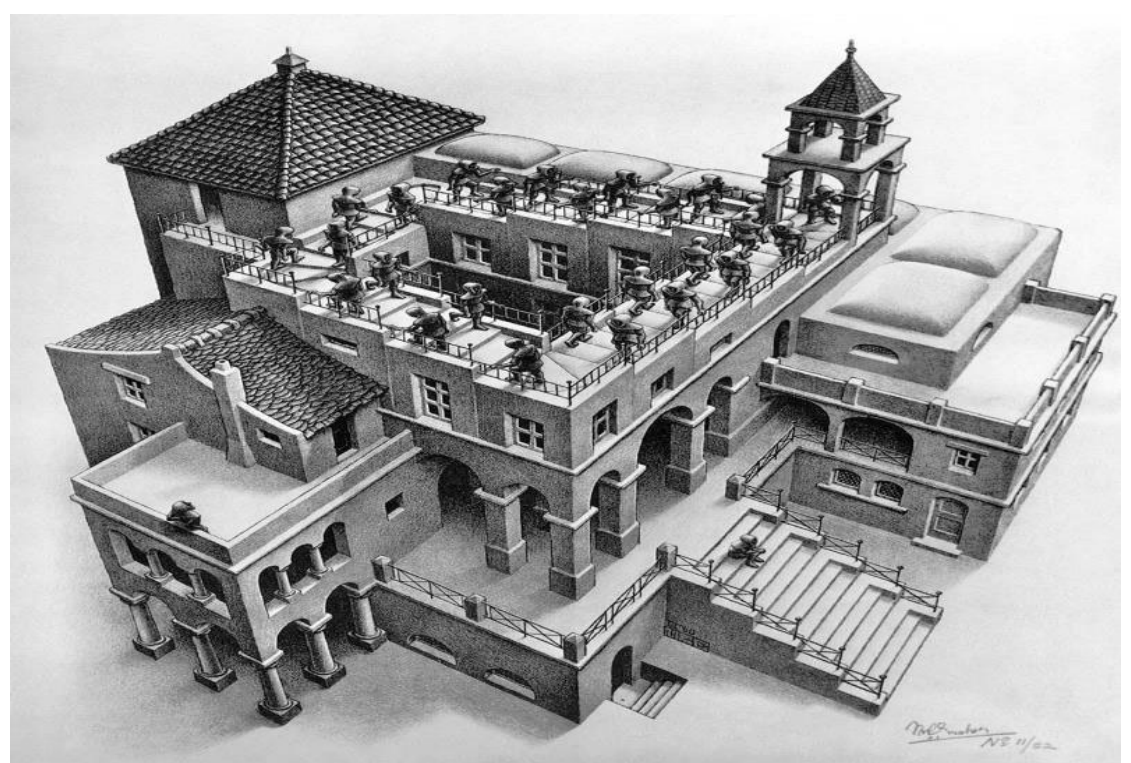

Figura 3: Ascending and descending, M. C. Escher, 1960

As voltas estranhas surgem de um antagonismo entre finito e infinito, entre real e imaginário, da composição de elementos que, a princípio, não poderiam ser justapostos na elaboração de uma teoria, melodia ou desenho. Hofstadter lança mão 


\section{Aoristo)))))}

International Journal of Phenomenology, Hermeneutics and Metaphysics

de exemplos nas artes, na matemática e na lógica para abordar uma questão que está estreitamente ligada com os objetivos do projeto de IA, qual seja, a compreensão de que o pensamento humano se dá a partir do uso e seguimento de regras e axiomas.

No entanto, o pensamento humano parece não se submeter a princípios e limites de ordenamento que o impedem de dar prosseguimento a uma determinada linha de raciocínio ou pensamento. Não só a capacidade de raciocinar nos distingue das demais coisas, a própria atividade de pensamento possui algo de peculiar ao se mostrar capaz de transgredir as leis e princípios que regem o seu funcionamento. Isso nos leva a considerar a hipótese de que o pensamento humano pode não ser passível de o compreendermos como um processo mecânico.

Nossa capacidade de raciocinar tem sido considerada, muitas vezes, como aquilo que nos distingue das demais espécies; não deixa assim de parecer paradoxal, à primeira vista, tratar de mecanizar aquilo que é mais humano. Contudo, mesmo os gregos antigos sabiam que o raciocínio e um processo que segue padrões e, pelo menos em parte, comandado por leis enunciáveis. (HOFSTADTER, 2000, p. 21)

Ao mesmo tempo que nossa capacidade de produzir raciocínios e pensamentos segue regras, também é capaz de transgredi-las, o que se apresenta como um paradoxo, pois ela não parece seguir padrões quando realiza um movimento como o de uma volta estranha. Para que esse movimento heterodoxo se realize de forma completa, para que seja completada a volta em toda a sua circularidade, é necessário que sejam colocados em suspensão os princípios e regras do seu funcionamento.

As histórias da matemática e da lógica nos mostram que, quando determinados princípios e definições são estabelecidos, algo acontece no sentido de mostrar que eles não se aplicam a determinados casos. Conforme Hofstadter, uma das causas para que isso ocorra é a existência de uma assimetria entre a nossa intuição e os sistemas hierarquizados de regras que elaboramos com o objetivo de compreender $\mathrm{o}$ funcionamento das nossas próprias faculdades.

O mais famoso é o paradoxo de Russell. Pareceria que, na maioria dos casos, os conjuntos não são membros deles próprios - por exemplo, o conjunto das focas não é uma foca, o conjunto que contém apenas Joana D'Arc não é Joana D'Arc (um conjunto não é uma pessoa) - e assim por diante. Sob esse aspecto, a maioria dos conjuntos é "relativamente comum". Contudo, alguns conjuntos "auto-devoradores" realmente incluem-se a si próprios entre seus membros, como o conjunto de todos os conjuntos, ou o conjunto de todas as coisas exceto Joana D'Arc, e assim por diante. Claramente, todo conjunto ou é relativamente comum ou é auto-devorador e nenhum conjunto pode ser ambas as coisas. Ora, nada nos impede de inventar R: o conjunto de todos os 


\section{Aoristo)))))}

International Journal of Phenomenology, Hermeneutics and Metaphysics

conjuntos relativamente comuns. À primeira vista, $\mathrm{R}$ pareceria ser uma invenção relativamente comum - mas essa opinião deve ser revista quando nos perguntamos: "O próprio R é um conjunto relativamente comum ou auto-devorador?" Verificaremos que a resposta é: "R não é nem relativamente comum, nem auto-devorador, pois ambas as escolhas levam a um paradoxo". Tente! (HOFSTADTER, 2000, p. 21)

De acordo com Hofstadter, os paradoxos como o acima mencionado são originados pela auto-referência, fenômeno semântico que produz como resultado voltas estranhas.

Embora autores como Stephen Yablo (A paradox without self-reference, Analysis, $53,4,1993)$ afirmem que os paradoxos gerados pela auto-referência sejam apenas um dos tipos de paradoxo existentes, a compreensão no meio matemático e lógico é que ela, a auto-referência, é a principal causadora desse tipo de movimento do pensamento. Por essa razão, a forma de superar esse tipo de anomalia, que impede o pensamento de seguir adiante, seria através da sua exclusão do contexto cujo objetivo é o estabelecimento de uma simetria entre nossas intuições e os sistemas de axiomas hierarquizados.

Tal tarefa não envolveria grandes dificuldades se a auto-referência fosse um simples procedimento de aplicar o sentido de uma proposição a ela mesma. Mas não é o que nos mostra o exemplo, dado por Hofstadter, da formulação análoga do Paradoxo de Epimênides.

A sentença seguinte é falsa.

A sentença anterior é verdadeira.

A diferença com relação ao exemplo original do Paradoxo de Epimênides (Eu estou mentindo) é que o paradoxo acima é produzido em dois passos, enquanto a formulação original do paradoxo do mentiroso é produzida em um passo somente. Isso ocorre porque, na formulação análoga, o paradoxo não é gerado por um procedimento de auto-referência imediata das proposições que o constituem, mas por um procedimento de auto-referência mediado pelo estabelecimento de uma relação lógica entre elas,

[...] a 'culpa' dessa volta estranha não pode ser atribuída a nenhuma das sentenças - apenas à maneira como elas 'apontam' uma à outra". Do mesmo modo, cada uma das regiões locais de Ascending and descending, de Escher, e bastante legítima, e apenas a maneira pela qual elas são globalmente articuladas que cria uma impossibilidade. (HOFSTATER, 2000, p. 22).

Segundo ele, uma das tentativas de nos livrar dos paradoxos gerados pelo emprego das regras de um determinado sistema de axiomas hierarquizados foi a realizada por Bertrand Russell (1872-1970) e Alfred Whitehead (1861-1947) com a 


\section{Aoristo)))))}

International Journal of Phenomenology, Hermeneutics and Metaphysics

criação da teoria dos tipos. Hofstadter afirma que a teoria dos tipos consiste no banimento da auto-referência, tal ação se concretiza por meio da elaboração de um sistema de axiomas hierarquizados concebidos de tal forma que as proposições que o constituem devem ser todas do tipo autoexcludente, isso é, proposições cujo sentido não podem fazer referência a elas mesmas.

Segundo todas as aparências, portanto, esta teoria de tipos, que poderíamos também denominar "teoria da abolição das voltas estranhas", livra, com êxito, a teoria dos conjuntos de seus paradoxos, mas apenas ao custo de introduzir uma hierarquia de aparência artificial e de desautorizar a formação de certas espécies de conjuntos - tais como o conjunto de todos os conjuntos relativamente comuns. Intuitivamente, essa não é a maneira segundo a qual imaginamos os conjuntos. (HOFSTADTER, 2000, p. 23)

A tarefa de Russell e Whitehead alcançou um êxito restrito porque ela se remeteu exclusivamente aos paradoxos constituídos pelos axiomas da linguagem da teoria dos conjuntos. A teoria dos tipos não teve o mesmo sucesso quando aplicada às linguagens naturais, pois nessas, suas sentenças não estão impedidas de fazer a auto-referência, já que elas não guardam entre si uma hierarquia tão rígida quanto a da linguagem da matemática.

A teoria de tipos deu conta do paradoxo de Russell, mas nada conseguiu com relação aos paradoxos de Epimênides e de Grelling. Para as pessoas cujo interesse não ia além da teoria dos conjuntos, isso era suficiente, mas para os que se interessavam pela eliminação dos paradoxos em geral, parecia necessária uma "hierarquizacão" similar para impedir esse tipo de volta para trás na linguagem. Na base de tal hierarquia estaria uma linguagem-objeto. A referência aqui só pode ser feita a um domínio especifico - não a aspectos da própria linguagemobjeto (tais como suas regras gramaticais, ou sentenças especificas nessa linguagem). Para esse proposito haveria uma metalinguagem. (HOFSTADTER, 2000, p. 23)

Ou seja, os problemas de um nível de linguagem seriam resolvidos por uma linguagem de nível superior ad infinitum. Com isso seria criada uma cadeia de resolução de problemas que envolveria a realização de saltos de um nível para o outro, de uma linguagem de primeira ordem para uma metalinguagem. Com a linguagem ordinária não ocorre o mesmo, pois ela parece sanar a necessidade de uma metalinguagem ao não impedir que o fluxo do discurso continue em curso.

Os saltos, nas linguagens naturais, parecem se dar em níveis dentro do próprio sistema. Contudo, isto não altera muito as dificuldades em se compreender o que seja a consciência, por exemplo, já que esta não consiste simplesmente na realização de

$$
\begin{aligned}
& \text { José Atilio Pires da Silveira } \\
& \text { Toledo, n॰5, v. 1(2020) p. 124 163 }
\end{aligned}
$$




\section{Aoristo)))))}

\section{International Journal of Phenomenology, Hermeneutics and Metaphysics}

saltos de um sistema de axiomas para outro. Não é isto que parece ocorrer com os usos que fazemos das linguagens naturais.

Outra dificuldade parece estar na natureza da própria consciência que parece escapar aos esforços que ela mesma realiza para compreender a si própria. Uma das razões para isso estaria nas próprias características do cérebro humano.

[...] pode ser que, ao contrário dos motores de automóveis, nossos cérebros sejam sistemas teimosos e refratários, que não possam ser decompostos com precisão de nenhuma maneira. Atualmente, não temos ideia se nossos cérebros cederão as repelidas tentativas de dividi-los em camadas claras que possam ser explicadas em termos de camadas mais baixas, ou se, ao contrário, eles farão fracassar todas as nossas tentativas nesse sentido (HOFSTADTER, 2000, p. 777)

Além dos supostos limites do cérebro humano que representariam sérios obstáculos na compreensão de como somos capazes de realizar saltos inferenciais que nos permitem sair de uma situação paradoxal, Hofstadter salienta que os saltos inferenciais podem resultar da realização de movimentos mais complexos que o de subida de um nível inferior para um nível superior dentro de um sistema hierarquizado de regras. Para ele, nossa inteligência realiza movimentos complexos de idas e vindas entre os diferentes níveis de regras que o constituem. Esse tipo de recursividade produz as voltas estranhas. Quando tal movimento é executado os níveis inferiores não são totalmente passivos na sua transitividade com os demais, eles também exercem influência e produzem efeitos nas regras pertencentes aos níveis que lhes são superiores.

Acredito que as explicações de fenômenos "emergentes" em nossos cérebros - por exemplo, ideias, esperanças, imagens, analogias e, finalmente, a consciência e o livre-arbítrio - baseiam-se em uma espécie de volta estranha, uma interação entre níveis na qual o nível mais alto se volta em direção ao nível mais baixo e o influencia, ao mesmo tempo em que ele próprio é determinado pelo nível mais baixo. (HOFSTADTER, 2000, p. 779)

Hofstadter acredita que a explicação da consciência exige que sejamos capazes de descrever com maior precisão os movimentos complexos realizados por nossa inteligência na superação de obstáculos que, à primeira vista, se apresentam como intransponíveis. A compreensão dessas transposições só poderá ser alcançada quando o uso dos axiomas do sistema hierarquizado de regras que rege o funcionamento da nossa inteligência for melhor investigado. Para tanto, será necessário que a fluidez do seu movimento seja captada, o que exige uma flexibilidade na sua abordagem. 


\section{Aoristo)))))}

International Journal of Phenomenology, Hermeneutics and Metaphysics

Para lidar com toda a riqueza do sistema mente/cérebro, temos de ser capazes de deslizar confortavelmente de um nível para outro. Além disso, temos de admitir vários tipos de causalidade": maneiras pelas quais um evento em um nível de descrição pode "causar" a ocorrência de eventos em outros níveis. (HOFSTADTER, 2000, p. 779)

Embora Hofstadter considere necessário compreendermos o fluxo de emprego das regras do sistema de axiomas, se quisermos definir em que consiste a consciência, ele não deixa de salientar que também devemos levar em consideração o fato de que na base de todo esse sistema e da complexidade de seu funcionamento estão as leis da física.

Existe um famoso hiato entre duas linguagens discursivas: a linguagem subjetiva e a linguagem objetiva. Por exemplo, a sensação "subjetiva" da cor vermelha e o comprimento de onda "objetivo" da luz vermelha. Para muitos, elas parecem ser absolutamente inconciliáveis. Não penso assim. Como não creio inconciliáveis as duas visões das Mãos que desenham, de Escher - a do "interior do sistema", em que as mãos desenham uma a outra, e a do exterior, em que Escher desenha tudo. A sensação subjetiva do vermelho provém do vórtex de auto percepção no cérebro; o comprimento de onda objetivo e a maneira como as coisas são vistas quando você salta fora do sistema. Embora nunca ninguém possa saltar fora do sistema o suficiente para perceber a totalidade, não nos devemos esquecer de que ela existe. Devemos recordar-nos de que as leis físicas são o que faz tudo acontecer - bem lá embaixo, nos cantos e gretas neurais, demasiado remotos para que possamos atingi-los com nossos meios introspectivos de nível alto. (HOFSTADTER, 2000, p. 779)

Tal posição leva ao debate de se as leis da biologia seriam subalternas às leis da física. Sem entrar no mérito dessa discussão, entendemos que a relevância dada por Hofstadter às leis da física nos adverte que assim como há um nível de interação entre os axiomas que constituem um determinado sistema hierarquizado, também há uma interação entre esses axiomas e o ambiente no qual eles se dão.

As voltas estranhas são realizações do pensamento que ao serem consideradas de um determinado ponto de vista não parecem fazer sentido, contudo, quando procuramos as razões disso, não as encontramos.

\section{CONCLUSÕES}

Para finalizar, acreditamos que é possível avançar a reflexão acerca do projeto de IA forte e seu objetivo tão ambicioso, rompendo, primeiramente, com a demarcação 


\section{Aoristo)))))}

International Journal of Phenomenology, Hermeneutics and Metaphysics

dicotômica da reflexão; segundo, propondo um novo modo de relação entre os conceitos empregados numa explicação e, por último, criando um modelo cujo princípio de organização principal é o caráter não hierarquizado dos elementos que o constituem. O que deveremos fazer, num próximo trabalho, é a apresentação de uma aplicação dessa sugestão por meio da construção de uma volta estranha envolvendo o uso dos conceitos de homem, artifício e inteligência. E, assim, sustentar a tese de que o projeto de IA forte é, ao menos, admissível.

\section{REFERÊNCIAS}

AUSTIN, J. L. Sentido e Percepção. Trad. Armando Manuel Mora de Oliveira. São Paulo: Martins Fontes, 1993.

. Philosophical Papers. Oxford: Clarendon Press. 1961.

COSTA, Newton da. Aquiles e a Tartaruga. Jornal de Resenhas. http://www1.folha.uol.com.br/fsp/resenha/rs1108200103.htm

DREYFUS, H. L. O que os Computadores não podem Fazer - Uma Crítica da Razão Artificial. Rio de Janeiro: Eldorado, 1975.

HOFSTADTER, D. Gödel, Escher e Bach. Um entrelaçamento de gênios brilhantes. Trad. José Viegas Filho. Universidade de Brasília: São Paulo: Imprensa Oficial do Estado, 2001.

KOSELLECK, R. Estratos do tempo: estudos sobre história. Trad. Markus Hediger. Rio de Janeiro: Contraponto; PUC-Rio, 2014.

PENROSE, R. Lo grande, lo pequeno y la mente humana. Trad. Javier García Sanz. Cambridge University Press: Madrid, 1999.

. Shadows of the mind: a search for the missing science or consciousness. Oxford, UK: Oxford University Press, 1996.

. The emperor's new mind. Oxford, UK: Oxford University Press, 1999.

RORTY, R. A filosofia e o espelho da natureza. Trad. Antônio Trânsito. Rio de Janeiro: Relume-Dumará, 1994.

TURING, A. Computing machinery and intelligence. In: FEINGEMBAUM \& FELDMAN (eds.). Computers and thought. New York: McGraw-Hill, 1968, p. 11-35.

. Computing machinery and intelligence. In: BODEN, Margaret (ed.). The Philosophy of

Artificial Intelligence. Oxford: Oxford University Press, 1990, p. 40-66.

WERLE, M. A. A Subjetividade como Fundamento da Técnica. In: Aoristo - International Journal of Phenomenology, Hermeneutics and Metaphysics. 2019, n.4, v.1, p. 59-70.

YABLO, S. A paradox without self-reference. In: Analysis. n. 53, v.4, 1993.

Submetido: 2 de fevereiro de 2020

Aceito: 2 de março de 2020

Ulma indicação sobre como tratar filosoficamente o problema da inteligência artificial 